\title{
Frequency vs. Size of Bank Fines in Local Credit Markets
}

\author{
Francesco Marchionne ${ }^{1} \cdot$ Michele Fratianni $^{1,2} \cdot$ Federico Giri $^{2}$ D Luca Papi $^{2}$
}

Received: 22 September 2020 / Accepted: 10 June 2021 / Published online: 26 June 2021

(c) The Author(s) 2021

\begin{abstract}
We examine how banking supervisors affect credit at the local level by charging fines to individual banks. Using a macro approach to capture the direct effect on the fined bank and the indirect effect on the other banks operating in the local credit market, we estimate reputational, reallocation and balance sheet effects on Italian provinces over the period 2005-2016 by a fixed effects model and instrumental variables. Provincial gross bank loans expand after a fine independently of its size. The impact of fine frequency depends on the size of the provincial banking sector, but neither on bank governance/ownership nor crises. No statistically significant evidence supports reputational or balance sheet effects. Instead, our results suggest that it would behoove bank supervisors to favor frequency over size of bank fines. Bank fines seem to work more like a good housekeeping seal of approval, enhancing transparency and effective banking practices.
\end{abstract}

Keywords Fine frequency $\cdot$ Fine size $\cdot$ Bank credit $\cdot$ Local markets $\cdot$ Supervision

JEL Classification $\mathrm{G} 01 \cdot \mathrm{F} 14 \cdot \mathrm{F} 18$

Francesco Marchionne

fmarchio@indiana.edu

Michele Fratianni

fratiann@indiana.edu

Federico Giri

f.giri@staff.univpm.it

Luca Papi

1.papi@univpm.it

1 Kelley School of Business, Bloomington, IN, USA

2 Department of Economics and Social Sciences, Università Politecnica delle Marche, Ancona, Italy 


\section{Introduction and Theoretical Underpinnings}

This paper examines how banking supervisors influence credit at the local level-in our case the Italian geographical area defined by the province-by charging fines to banks in breach.

Enforcement actions by bank regulators-in our case the Bank of Italy (BI) occur typically in the aftermath of on-site inspections and may include pecuniary fines, prompt corrective actions, temporary cease and desist orders, and moral suasion initiatives. Most of these measures are kept strictly confidential, while a few are publicly disclosed and available to researchers. We restrict the domain of enforcement actions to published pecuniary bank fines and estimate their overall effects on Italian provinces for the period 2005-2016. In contrast to previous bank-level studies, we use aggregate data to capture both the direct impact of the sanctioning process on the fined bank and the indirect effect emanating from other banks' reactions. The latter is crucial for the analysis of the local credit market because with several banks serving the same local market, the indirect effect may dominate the direct one. ${ }^{1}$ The macro approach, furthermore, offers two statistical advantages. First, it reduces the sample selection distortion and biased estimates resulting from severely unbalanced bank-level panel data. Second, it does not suffer from the efficiency loss due to the increase in the number of estimated variables and reduction in the number of usable observations that instead affect unbalanced bank-level panel data.

We hypothesize three transmission channels from pecuniary bank fines to provincial credit. The first is a balance sheet effect. Say an inspection reveals a breach in the classification of loans; the fine may come with a correction to shift some loans from the "good" category to the impaired loan category. The consequence of this action is an additional write-down due to the higher non-performing loans (NPL). If the bank absorbs the pecuniary fines charged to the management through higher compensation or more insurance protection, the cost of the fines affects the bank's capital ratios and income account.

If, instead, the inspection reveals a systematic management strategy of supporting friendly "zombie" firms, the fine will generate effects that go beyond an accounting adjustment: the bank in breach will be obliged to reduce its loan portfolio to lower its risk-weighted asset indicator to restore the prescribed capital and financial ratios. This second transmission mechanism of asset repricing and resizing will be larger in provinces with a concentrated banking sector, and smaller in provinces with more competitive credit markets. The indirect effects of the fine will include the reaction of rival banks with similar asset allocation of the offending bank, but yet not found in breach by the regulator; the rival banks will be induced to act preemptively by making adjustments in the classification of loans and write-downs. In time, a more transparent credit procedure would promote a more diversified allocation of resources

\footnotetext{
1 The macro approach is also justified by the importance of fines as part of an enforcement mechanism of bank supervision. The supervisor's ultimate goal is the real economy, not the single bank; by enforcing the rules, the supervisor reduces unfair credit discrimination and promotes firm investment and economic growth.
} 
that, in turn, would raise bank efficiency and lead to an expansion of credit, for the same level of risk or a reduction of overall risk for the same level of credit. We call the second transmission mechanism the (provincial) reallocation effect.

The third transmission channel involves the role of borrowers. A sanctioned bank loses reputation; as a result, part of the demand for its loans is diverted elsewhere. If the market believes that the sanctioned practice is specific to the fined bank, the provincial loan supply will not change: the loss of credit suffered by the sanctioned bank will be compensated by the gain in credit supplied by other banks. But, if the market suspects that other banks may have followed the practice of the sanctioned bank, the provincial demand for credit would decline. We call this demand-side driven reaction to bank fines the reputational effect. In sum, we have three channels-balance sheet, reallocation, and reputation-that occur at different times after an inspection assessing a bank fine. With our annual data, we can disentangle the impact on provincial credit of each of the three distinct channels (through separate estimated coefficients), but not their timing sequence. In the empirical part of the paper, we will see that only the reallocation channel is statistically significant; the other two are not. Therefore, as a practical matter, the importance of the timing sequence of the three channels becomes less important.

The motivation for focusing on the Italian provincial credit market stems from the fact that the Italian economy, with its emphasis on small and medium-sized firms, is extremely dependent on bank credit: numerous small local banks and large national banks compete at the provincial level. ${ }^{2}$ The spatial overlap of small local banks and national banks in the provincial credit markets provides a suitable environment to study the effects of bank fines and their spillovers along the lines outlined with the three transmission channels. On the other hand, bank competition in Italian provinces works against our hypothesis of the effectiveness of bank fines because credit supply adjustments tend to be smaller in competitive markets, whereas our hypothesis tests for their presence. Low pecuniary fines and high NPLs also work against our hypothesis because bank fines are spread over multiple provinces, which further reduce their impact on local credit supply, and the effects of the corrections to NPLs are harder to detect at the provincial level. Lastly, we use total loans as the dependent variable because the data on NPLs, our preferred choice, have many missing values. ${ }^{3}$ As many accounting adjustments occur between good and impaired loans, it also works against our hypotheses. In brief, our hypothesis faces headwind forces; to the extent that Italy represents a tough case for our hypotheses, our findings are more likely to hold also in other, less competitive, environments.

The selection of the sample period was determined by data availability and institutional reforms. In particular, the starting year of 2005 coincides with a

\footnotetext{
${ }^{2}$ The number of banks in Italy has decreased from 698 in 2008 to 497 in 2016. The sample average value of the provincial bank Herfindahl-Hirschman index (computed on the basis of provincial shares of bank branches) is 0.15 out of a maximum of 1 . The low concentration of bank branches suggests a quite competitive sector.

${ }^{3}$ It creates a further bias against finding an effect of bank fines on provincial credit supply because the bulk of balance sheet adjustments occurs in the loan category.
} 
reclassification of accounting items; the choice of the terminal date of 2016 is due to the approval of three main institutional and legal reforms that altered the governance structure of popular and cooperative banks and reorganized the whole sanctioning process; see section II below.

This paper contributes to the related literature in several respects. The first is that our empirical results at the local credit market level refute the literature on the negative effects of enforcement actions on bank performance. Our findings are close to the most recent papers, such as Leuz and Granja (2019) and Hirtle et al (2019), corroborating that bank loans expand after a bank sanction. We find that provincial credit supply is sensitive to the frequency of fines, but not to the amount of the fines. The imposition of fines, after an initial change in loan classification, can induce sanctioned banks and other banks in similar situations to revisit their lending and risk management practices, in turn leading to credit reallocation and loan expansion. The second contribution is that the paper identifies three potential effects of bank fines on local credit-balance sheet effect, the reallocation effect, and the reputational effect-and suggests a specific empirical strategy to identify them. The third contribution recognizes that the reallocation effect is the dominant one, whereas no evidence was detected for the other two effects. Finally, the impact of bank fine frequency on provincial credit is sensitive to the size of the provincial banking sector, but not to bank governance or to the crisis period of 2008-2012.

Our findings have policy implications. Supervisors may differentiate the frequency of fines among different types of banking institutions. Italian regulators have historically made a distinction between one-member-one-vote mutualistic banks and larger national joint-stock banks (Giordano 2007). Our paper finds no evidence of a similar distinction in bank governance on the effects of supervision. Instead, breaches interact negatively and significantly with bank size, the implication being that provinces with a large bank sector require a higher frequency of bank fines than provinces with smaller bank sectors to offset the drag on provincial bank credit due to larger bank size. With an average provincial bank size of $€ 4.1$ billion, $80 \%$ of Italian provinces find that the positive effect of fine frequency on provincial credit is actually more than compensated by the negative impact on credit due to provincial bank size. Our simulation shows that if fine frequency were to rise by $25 \%$, its positive impact on credit would dominate the negative impact due to bank size in all provinces. The inference is that the fine mechanism acts as a salutary monitoring device that spurs efficiency: bank supervision acts more as a good housekeeping seal of approval than as a policeman.

The rest of the paper is organized as follows. Section 2 summarizes the literature. Section 3 describes the sanctioning process. Section 4 deals with the adopted methodological approach and hypotheses. Section 5 presents data sources and descriptive statistics. Section 6 discusses the empirical strategy and our findings. Section 7 deals with robustness checks and presents the results of a simulation exercise that evaluates the contrasting forces at work in the empirical findings. Conclusions are drawn in Sect. 8. 


\section{Related Literature}

The literature on the effects of banking supervision on local credit markets is of relatively recent vintage and is not very extensive. We group studies according to our three transmission channels: the balance sheet effect, the reallocation effect, and the reputational effect.

A first strand of the literature takes a microeconomic perspective in analyzing the effects of bank supervision on bank performance. The empirical works typically focuses on supervisory output data, such as on-site inspections, and resulting formal enforcement actions, which estimate the effectiveness of bank supervision more precisely than earlier research based on supervisory input indicators. Using US data, Peek and Rosengren (1995) investigate the direct link between supervisory actions carrying civil penalties and the dynamics of loans in bank dependent sectors: banks subject to formal enforcement actions shrink credit activity at a faster rate than those with no enforcement actions. This is consistent with our balance sheet effect. Delis and Staikouras (2011) examine whether supervisors inspecting banks more regularly and adopting stricter enforcement are better positioned to restrain banks' risk-taking appetite, an issue we take up in our empirical work. The authors, in line with our balance sheet channel, find that the impact of on-site examinations on their measures of bank risk is non-linear with a relatively high threshold level of audits beyond which their relationship with risk becomes negative. Agarwal et al. (2014) note that stricter supervision in the US, due to the mandatory rotation between state and federal regulators, leads banks to deleverage and achieve higher capital ratios. Similarly, but for euro area banks, Eber and Minoiu (2016) study the effects of stricter supervision scrutiny on bank balance sheets and find that European banks adjust to stricter supervision by shrinking assets-especially securities-rather than raising capital. Based on a US sample, Delis et al. (2017) assess the effect of formal enforcement actions directly in relation to core financial safety and soundness. Their findings suggest that enforcement actions reduce risk-weighted assets, principally through less lending and NPLs.

A second strand of the literature follows an aggregated approach in analyzing the impact of supervisory actions on macroeconomic variables. Bassett et al. (2015) show that elevated supervisory stringency has a noticeable dampening effect on future lending activity. The authors estimate the relationship between changes in CAMELS ratings and changes in small businesses lending and find that small banks with rating downgrades during 2007-2010 exhibit lower lending growth to small businesses compared with banks with unchanged ratings. For Germany, Berger et al. (2016) show how supervisory actions disrupt liquidity creation. Danisewicz et al. (2017) use a macro approach to examine at the level of US counties how enforcement actions on banks and liquidity creation exert negative effects on per-capita income growth, the number of establishments and unemployment with the identified macro-financial linkages operating through reductions in bank lending. However, these adverse effects on the real economy seem to be temporary and typically last 1 year. Finally, analyzing the Italian case, Caiazza et al. (2018) focus on spillovers of enforcement actions on 
non-sanctioned banks under the assumption that sanctions serve the twin objectives of penalizing the offending banks and warning other banks. The authors find that credit risk-related fines assessed on Italian banks reallocate lending in a way that non-sanctioned banks tend to behave more similarly to sanctioned bank, evidence bearing on our reallocation effect channel.

Apart from the last paper, all cited studies tend to associate closer supervision with bank deleveraging and adopting tighter criteria in making new loans, a finding that tends to support the balance sheet effect, operating through significant asset resizing. Moreover, stricter supervision seems to have a disciplinary impact upon sanctioned banks through more effective market discipline, which in turn could trigger the reputational effect resulting from public disclosure of audits' findings and more transparent financial reporting.

The above negative relationship between enforcement actions and lending activity growth raises a welfare concern about the effectiveness of banking supervision: does stricter supervision have a negative effect on credit growth and economic activity? On this question, the literature is far from being conclusive. A few recent papers corroborate the prevalence of the reallocation effect over the balance sheet and reputational effect, suggesting that stricter supervision can boost credit growth. For example, Leuz and Granja (2019) show for the US that the transition from a more to a less tolerant supervision raises the amount of loans disbursed to small business, suggesting a positive value added by more demanding supervisors. Their findings also suggest that stricter supervision can overcome frictions in bank management and raise the amount of loans, indirect evidence in favor of the dominance of the reallocation effect. Echoing Leuz and Granja, Hirtle et al. (2019) underscore the positive contribution of supervision in mitigating banking sector risk. Exploiting the structure of the US supervisory system, the paper finds that Federal Reserve examiners spend proportionally more time at the largest banks in their district, and those banks hold less risky loan portfolios and are less sensitive to industry downturns, without experiencing adverse consequences on their growth or profitability. While the authors do not discuss the specific channel which may account for their findings, they posit that more attentive supervision may assuage principal-agent problems and hence promote a more careful risk-taking assessment. For example, a recent contribution by Bonfim et al. (2020) finds that on-site inspections of bank credit portfolios by Portuguese bank supervisors reduce future lending to "zombie" firms. This positive outcome, furthermore, lasts when inspectors are long gone. The implication is that either sanctioned banks learn from the supervisors or they take into account the threat and the costs of future inspections. Both explanations are consistent with the idea that on-site supervision can affect future bank lending decisions providing additional evidence of the role played by the reallocation effect.

Another successful impact from enforcement actions is provided by the analysis of the syndicated loans sector by Deli et al. (2019), where a causal effect emerges of financial penalties on the cost of borrowing: the cost of loans originated after a bank receives a fine is significantly lower compared to loans originated before the fine. This finding can be attributed to competitive and reputational effects: a fine makes the sanctioned bank less reputable and consequently may induce management to apply better lending terms to retain customers. According to the authors, 
this effect persists for about four years after the sanction has been levied and constitutes a strong welfare case for enforcement actions.

Our brief review of the literature highlights a variety of outcomes on the impact of enforcement actions on bank credit. We have seen that sanctions affect not only the behavior of the offending banks, but also that of the non-sanctioned banks. In our paper, the effects on these two groups of banks emerge indirectly because our key variable is provincial credit, where both sanctioned and non-sanctioned banks operate. In sum, whether less lenient supervision reduces or boosts lending and the economic activity remains an empirical issue. We note that, apart from Danisewicz et al. (2017), published papers have not analyzed the local aggregate impact of bank fines. Passalacqua et al. (2020) apply a diff-in-diff estimation to a proprietary (Bank of Italy) dataset on a subset of Italian banks, banche di credito cooperativo $(B C C)$. Their working paper finds that bank inspections exert a negative, temporary, balance sheet effect on inspected banks (by forcing write-offs) and a positive reallocation spillover for healthy firms (by squeezing zombie lending). These results suffer, however, from identification and endogeneity problems that the authors mitigate by using bank subsamples, thus reducing the general validity of their findings. ${ }^{4}$ Yet, the authors use the results on BCCs to provide a more general interpretation of their findings.

Our paper applies data from the Italian banking universe to a growth model of credit, and it estimates the overall impact of bank supervision on the real economy at the provincial level. By design, this approach does not suffer from selection bias because we consider all the banks. We address endogeneity issues with instrumental variables. Our work, in sum, intends to fill the gap in the literature on the connection between bank supervision and local (provincial) credit.

\section{Institutional Background}

$\mathrm{BI}$ is the supervisory authority of the Italian banking sector, jointly with the European Central Bank (ECB) since 2012. The sanctioning process of BI is regulated, at the primary level, by law and, at the secondary level, by various norms issued by BI. ${ }^{5}$ Within this legal framework, BI has been empowered to levy administrative fines to banks in breach of regulations designed to protect the sound and prudent management of banking activity, the correctness and transparency of conduct, and the prevention of money laundering. The main entities subject to the sanctioning

\footnotetext{
${ }^{4}$ For their identification, the authors rely on the Bank of Italy's Inspection Plan, an unpublished computer-based selection rule to classify and rank banks eligible for inspections; for that, several criteria, including geographical proximity, are employed. This quasi-random algorithm is assumed to generate surprise inspections. However, due to limited resources, the supervisory authority arbitrarily adds eligible banks based on insiders' information.

5 For the law, see the Legislative Decree n. 385 of 1 September 1993.
} 
procedure are people in bank administration, management, and control, and auditing entities. ${ }^{6}$

Recently, a major revision of the sanctioning process was undertaken at the European level. It started in July 2011 with the Capital Requirements Regulation (CRR) and the Capital Requirements Directive (CRD IV) and it was aimed at defining in more detail, among other things, the sanctioning process for banks. The maximum fines were set, in principle, at a dissuasive level, that is to nullify the incentive perpetrators may derive from a breach. The same objective was set for other measures, such as public reprimands, orders to cease, and temporary suspensions of functions. In May 2016, the Italian regulatory framework was made compatible with the European one, a change that has no direct bearing on our research given that 2016 is the end of our sample period. ${ }^{7}$

We recall that Italy has a dual banking system, where a significant number of mutual banks coexist alongside few national banks. In addition to serving local markets, mutual banks differ from joint-stock banks in that their depositor-members can cast only one vote irrespective of the amount of their capital shares; so memberbased governance is also another characteristics of mutual banks.

The two main groups of local banks are banche popolari $(B P)$ and banche di credito cooperativo $(B C C)$. A 2015 law restructured BPs to alter the traditional governance principle (Visco 2018). According to this law, BPs with total assets in excess of $€ 8$ billion had either to convert into a joint stock legal structure or reduce their size below $€ 8$ billion. A 2016 law restructured BCCs with the objective of increasing economies of scale and scope and improving the quality of management. Each BCC had the option of either becoming a joint-stock company (and thus give up the one-member-one vote governance) or joining a group of BCCs anchored to a joint-stock parent bank. The intent of the law was to engineer consolidation, risk diversification, and reduce opaque or friendly lending (Coccorese and Shaffer 2018). Both laws, whose draft proposals were debated for years, accelerated the process of bank consolidation through the formation of holding group structures. ${ }^{8}$ The ensuing consolidation process was largely anticipated by banks and could have reduced differences in governance way before 2016.

\footnotetext{
${ }^{6} \mathrm{BI}$ ascertains violations, conducts preliminary investigations, and imposes pecuniary fines. The sanctioning procedure is divided into the following phases: assessment of violations; dispute of violations; presentation of rebuttals and possible personal hearings; evaluation of all relevant instructive elements; proposal to BI Directorate for the imposition of fines or dismissal of the proceeding; adoption of the sanctioning provision or filing of the proceeding by the Directorate; notification and publication of the provision containing the details of the levied fine.

7 An indirect effect could have occurred with the banks anticipating the new regulatory framework.

8 The empirical evidence about the role of small local banks versus large commercial bank on economic growth is vast but inconclusive suggesting that there is no optimal bank size. Many papers find a positive impact of small local banks on regional growth, corroborating the presence of comparative advantages of small institutions in acquiring and using soft information through personal and repeated interactions with local customers. For instance, in the case of Italy, Lucchetti et al. (2001), Usai and Vannini (2005), Coccorese and Shaffer (2018) find positive effects of the presence of small cooperative banks on local economic growth. In contrast and more recently, Stefani et al. (2016) show that during the great financial crisis local banks' lending policies were riskier, produced more NPLs, eventually outweighing the benefits of customer proximity and personal relationships.
} 
Our paper focuses on the outcome of the supervisory process leading to fines levied by BI, the only information in the public domain. We collected data on pecuniary fines over the period 1998-2014 from the BI Monthly Supervision Bulletin and for 2015-2016 from BI's website. For each fine we also collected the monetary amount disaggregated by the area of infringement, and for sanctioned people. Breaches related to credit risk disclosure and management, internal controls, conflict of interest and governance were aggregated under the rubric of credit and credit-related violations $(B C)$, whereas breaches related to money laundering, salary and compensation, transparency, and controls exercised by the Supervisory Board were grouped under the rubric of non-credit violations $(B O)$. Our classification is somewhat similar to that by Caiazza et al (2018) but differs in that we have a more expansive list of breaches. ${ }^{9}$ Furthermore, in our empirical work we treat fines both as dummy variables and pecuniary values, whereas Caiazza et al. (2018) use only dummy variables.

Our annual data do not allow to estimate the timing of the effects of our three transmission channels. However, the overall duration of the sanctioning process is crucial to determine the lag structure of the empirical model. Three factors are at play: the duration of the inspections culminating in a fine, the impact of the fine on the bank in breach, and the spillovers from the fined bank to other banks operating in a province. The duration of an inspection depends on various factors such as the type of inspection, its results, and the size of the bank. According to Passalacqua et al. (2020, p 14), on-site inspections last, on average, 66 days, but there is a great spread around this average. Within 90 days from the end of the inspection, inspectors submit their findings and observations to the management of the inspected bank. The recipients have up to 30 days to respond (BI 1999, Titolo VI, Capitolo 4, Sezione II). If the inspectors uncover a sanctionable infraction, BI has 90 days to notify the sanction to the bank and relevant parties; these are given 30 days to respond. The final decision on the sanction, taken by BI, can take up to 240 days (BI 1999, Titolo VII, Capitolo 1, Sezione II; BA 2012, Sezione II). The two procedures, inspection and sanctioning, can well stretch beyond a year. To that one must add the time related to the impact of the fine on the activities of the bank in breach and the time required for the spillovers to unfold from the bank in breach to other banks operating in a given province. ${ }^{10}$ In sum, the timing of the effects of the three transmission channels across the inspection process, the bank in breach, and spillovers to other banks is such to justify a dynamic specification of our empirical model.

\footnotetext{
${ }^{9}$ Our list of breaches includes deficiencies in matters of credit risk management, organization and internal controls, conflict of interest, governance, credit risk disclosure to the Supervisory Authority, money laundering, salary and compensation, transparency, controls exercised by Supervisory Board, and other failures.

10 Passalacqua et al. (2020, pp 3-4, Fig. A6) estimate that accounting adjustments, like increases in estimated NPLs and loan loss provisions, occur, on average, in the quarter following an on-site inspection, while asset resizing take longer, between 6 and 9 months.
} 


\section{Methodology and Hypotheses}

For our empirical investigation we use a credit model at the provincial level built around a standard economic growth model (Barro 1991; Mankiw et al 1992; King and Levine 1993; Levine et al 2000; Law and Singh 2014). The growth of gross provincial bank credit $\left(\Delta \ln C R_{j, t}\right)$ depends on the log of its lagged level $\left(\ln C R_{j . t-1}\right)$, a demand factor given by the current growth of per-capita GDP $\left(\Delta \ln Y p c_{j, t}\right)$ and a supply factor given by a set of lagged provincial control variables $\left(C T R L_{j, t-1}\right)$. These include a measure of bank liquidity captured by the ratio of bank liquidity to total bank assets $\left(L R_{j, t-1}\right)$, a measure of bank leverage captured by the ratio of total bank assets to bank equity $\left(L E V_{j, t-1}\right)$, a measure of bank concentration captured by the Herfindahl Index of bank branches in the province $\left(H I_{j, t-1}\right)$, and a measure of bank profitability given by the ratio of bank profits to bank total assets $\left(R O A_{j, t-1}\right)$.

According to different specification of the model, we augment our model to include a measure of bank fines frequency, $B C n$, and a measure of bank fines amount, $B C a$. The full model and the relative testable implications are summarized in the following equation:

$$
\begin{aligned}
& \Delta \ln C R_{j, t}=\alpha_{0}+\alpha_{1} \ln C R_{j, t-1}+\alpha_{2} \Delta \ln Y p c_{j, t}+\alpha_{3} C T R L_{j, t-1}+\theta_{t}+\mu_{j}+\varepsilon_{j t} \text { (base) } \\
& +\gamma_{1} B C n_{j, t-1}+\gamma_{2} B C a_{j, t-1}+\gamma_{3} B C n_{j, t-1} \Delta \operatorname{lnYpc} c_{j, t}(\text { HYP } 1-3) \\
& +\delta_{1} B C n_{j, t-1} X_{j t}+\delta_{2} B C a_{j, t-1} X_{j, t} .(\text { HYP } 4-5)
\end{aligned}
$$

$B C n$ works through a credit reallocation process: the bank is sanctioned because of risky and non-transparent practices skewed towards higher-risk loans. The discovery of the breach, followed by a fine, lowers the bank manager's risk-taking preference and raises his or her incentive to achieve a more diversified, efficient, and transparent loan portfolio, i.e. with fewer loans to zombie firms. Other banks, in a similar situation, could preemptively adjust their loan portfolio to dodge a fine. The aggregate impact is affected by the distribution and exposure of banks operating in the provinces. The testable implication is that receiving fines has a positive impact on bank credit due to the reallocation effect; this is HYP $1: \gamma_{1}>0$. Its alternative is that supervision is driven by political goals and aims at making zombie firms survive.

The second fine variable, $B C a$, acts as a pecuniary cost borne by the sanctioned bank. Even if the provincial impact is proportional to the exposure of the fined bank in a province, competing banks, in a similar situation, could also expect a fine and decide to raise pre-emptively reserves. The testable implication is that this cost has a negative impact on the bank's balance sheet and hence on bank credit; this is HYP 2: $\gamma_{2}<0$. The alternative is that a fined bank takes more risk because it relies on an implicit safety net.

The third effect arises with the public losing trust in banking when an individual bank is fined. The stigma can either be limited to the sanctioned bank or generalized to other banks at the provincial level. In such a case, the banking system as a whole 
loses credibility and borrowers switch to other sources of financing. The testable implication is that bank credit will be less sensitive to a demand variable like Ypc and that the interaction between $Y p c$ and bank fines will affect bank credit negatively; this is HYP 3: $\gamma_{3}<0$. The alternative is that the breach raises confidence and trust in the banking system because the "bad" bank was identified and punished. The three hypotheses appear in the second line of Eq. (1).

Finally, we test for possible asymmetric effects due to the dominance of different types of bank governance or bank size in the province. Differences between banks reflect the specific nature of mutual or community banks and large joint-stock banks. These two types of banks may differ in terms of governance: ownership staff management and board of directors are always locally based in the case of mutual banks (Fonteyne 2007; Kim and McKillop 2019) and size affects the capacity to obtain and process hard and soft information (Alessandrini et al 2010). Banks interaction at the provincial level could show aggregate effects beyond the bank level. HYP 4 tests whether the provincial impact of fines may be sensitive to bank size, measured as the logarithm of total credit, rather than to bank governance (see the third line of Eq. 1). In particular, our hypothesis is that fines to large banks are geographically less specific than fines to small banks; hence they send a weaker signal and have a smaller impact to the local credit market; this is HYP 4: $\delta_{1}<0$. Assuming that banks do not anticipate the reforms, HYP 5 proposes an alternative to HYP 4 , namely that the provincial impact of fines discriminates between mutual banks (noSPA) and joint-stock banks (SPA). In this case, in sympathy with the extended literature on positive effects of mutual and community banks on local credit, our hypothesis is that bank fines to large banks have smaller negative effects on local credit; this is HYP 5: $\delta_{2}<0$.

In a nutshell, our null hypotheses can be summarized as follows:

\begin{tabular}{ll}
\hline Null Hypothesis & Description \\
\hline $\mathrm{HYP}_{0}: \gamma_{1}>0$ & Reallocation effect hypothesis \\
$\mathrm{HYP} 2_{0}: \gamma_{2}<0$ & Balance sheet effect hypothesis \\
$\mathrm{HYP}_{0}: \gamma_{3}<0$ & Reputational effect hypothesis \\
$\mathrm{HYP}_{0}: \delta_{1}<0$ & Bank size hypothesis due to \\
& weaker local effects of large \\
& banks \\
$\mathrm{HYP}_{0}: \delta_{2}<0$ & Bank ownership hypothesis \\
& due to weaker local effects of \\
& joint-stock banks \\
\hline
\end{tabular}

\section{Descriptive Statistics}

Our dataset includes 989 supervisory interventions leading to 1930 pecuniary fines. Figure 1 shows the evolution of $B C$ and $B O$ expressed in euro amounts from 1998 to 2016 . The early years, 1998-2004, display a relatively minor sanctioning activity; we omitted them from the sample. To arrive at a homogeneous sample, 


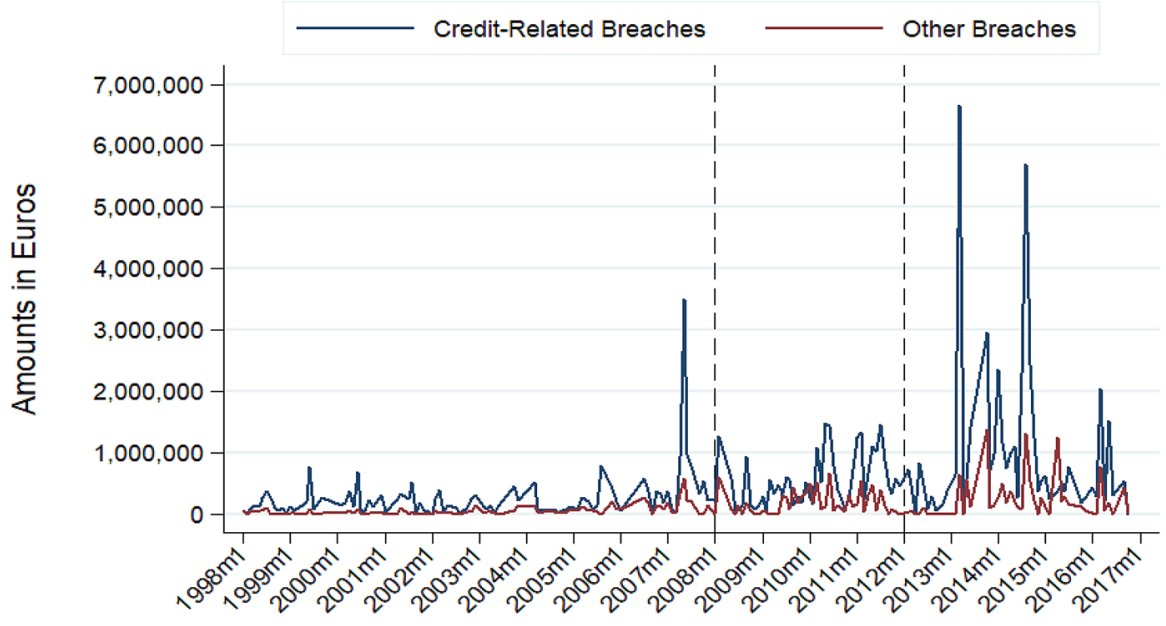

Time

Fig. 1 Bank fines, 1998-2016

we chose 2005 as the starting year of our analysis because in that year a new accounting classification was introduced. In the same vein, we selected 2016 as the terminal year because relevant changes occurred in the legal banking framework (and institutional change in mutual banks' governance and a new sanctioning process). As to the size of bank fines, Fig. 1 underscores that $B C$ fines are higher than $B O$ fines. The two series, on the other hand, are positively correlated. In the empirical work, we use $B C$ as a determinant of bank credit, whereas $B O$ is employed as an instrument to handle potential endogeneity between bank credit and $B C$. The intuition is that the absence of non-credit fines signals to the regulator a general disposition of legality in the banks operating in the province, whereas the absence of credit-related fines is a manifestation of legality in a specific sector.

Concerning the remaining data, we drew accounting data of Italian banks from Associazione bancaria italiana (ABI). All data-accounting and fine data-have an annual frequency and were transformed from individual-bank data to provinciallevel data. This transformation was done by multiplying balance sheet data for each bank by the ratio of its provincial branches to its total branches at the national level. The final dataset is obtained by summing each variable of interest at the provincial level; see Appendix for further details.

Tables 1 and 2 presents descriptive statistics both at the bank level and at the provincial level respectively. In Table 1 (bank level), the first five variables -credit, liquidity, total assets, equity and profits- are in thousands of euros whereas the next three variables are ratios; $L R$ is liquidity as a ratio of total assets, $L E V$ is leverage measured as total assets divided by equity; $R O A$ is return on assets. The next group of variables-SPA, noSPA, BCC, BP and CRISIS - are dummy variables. In particular, CRISIS is a dummy equal to 1 from 2008 to 2012 capturing both the great 
Table 1 Bank-level descriptive statistics, sample 2005-2016

\begin{tabular}{|c|c|c|c|c|c|c|c|c|}
\hline Variable & Mean & SD & Median & Min & Max & Kurtosis & Skewness & Obs \\
\hline$C R$ & $2,603,830$ & $12,888,234$ & 289,605 & 0 & $2.61 \mathrm{E}+08$ & 194.27 & 12.565 & 6894 \\
\hline$L I Q$ & 948,658 & $7,178,660$ & 32,406 & 10 & $2.10 \mathrm{E}+08$ & 378.82 & 17.329 & 6894 \\
\hline$T A$ & $4,744,933$ & $25,391,911$ & 465,319 & 5141 & $4.48 \mathrm{E}+08$ & 188.79 & 12.623 & 6894 \\
\hline$E Q$ & 409,293 & $2,734,823$ & 47,232 & 1428 & $57,994,152$ & 278.55 & 15.848 & 6894 \\
\hline$P R O$ & 1923.4 & 300,946 & 1294 & $-11,601,111$ & $5,811,000$ & 779.21 & -20.826 & 6894 \\
\hline$L R$ & 0.1226 & 0.13618 & 0.079917 & 0.00004468 & 0.98963 & 14.887 & 3.1466 & 6894 \\
\hline$L E V$ & 11.131 & 6.8435 & 9.9642 & 1.0259 & 106.5 & 39.953 & 4.6144 & 6894 \\
\hline$R O A$ & 0.0021998 & 0.020362 & 0.0036019 & -0.66885 & 0.19282 & 345.66 & -13.061 & 6894 \\
\hline$S P A$ & 0.29634 & 0.45668 & 0 & 0 & 1 & 1.7956 & 0.89196 & 6894 \\
\hline noSPA & 0.70366 & 0.45668 & 1 & 0 & 1 & 1.7956 & -0.89196 & 6894 \\
\hline$B C C$ & 0.6275 & 0.48351 & 1 & 0 & 1 & 1.2782 & -0.52745 & 6894 \\
\hline$B P$ & 0.076153 & 0.26526 & 0 & 0 & 1 & 11.214 & 3.1959 & 6894 \\
\hline CRISIS & 0.47317 & 0.49932 & 0 & 0 & 1 & 1.0116 & 0.10749 & 6894 \\
\hline$B C a$ & 7032.1 & 103,877 & 0 & 0 & $7,154,200$ & 3379 & 52.485 & 6894 \\
\hline Воа & 1700.4 & 22,982 & 0 & 0 & $1,383,550$ & 1983 & 37.131 & 6894 \\
\hline
\end{tabular}

Labels: $S D$ standard deviation, $O b s$ observations

Variables: $L I Q$ liquidity (in thousands of euros), $T A$ total assets (in thousands of euros), EQ capital (in thousands of euros), PRO profits (in thousands of euros), $L R$ liquidity/TA ratio, $L E V$ leverage as total asset to equity, $R O A$ return on assets, $S P A$ dummy equal to 1 for joint stock banks, noSPA dummy equal to 1 for non-joint-stock banks, $B C C$ dummy equal to 1 for credit cooperative banks, $B P$ dummy equal to 1 for popular banks, CRISIS dummy equal to 1 for the period 2008-2012, BCa euro amount of creditrelated bank breaches, $\mathrm{BOa}$ euro amount of credit-unrelated bank breaches

financial crisis and the Italian debt crisis. The final group of variables reports creditrelated and non-credit related fines in euros.

Some aspects of the statistics are worth mentioning. $R O A$ is extremely low with a mean value of $0.22 \%$. Its distribution is extremely wide, ranging from a minimum of $-66.9 \%$ to a maximum of $19.3 \%$; there is a high number of outliers and the frequency distribution has a left tail. Regarding the corporate structure, $70 \%$ of Italian banks are either credit cooperative banks or popular banks; the remainder $30 \%$ are joint-stock banks. Bank fines average $€ 7032$ for credit-related breaches and $€ 1700$ for non-credit related breaches. The highest bank fine in the sample was $€ 7,154,200$. These amounts appear, at first sight, to be too small to expect a significant material impact on bank behavior. Our fine variable has a high number of outliers and its frequency distribution is leptokurtic.

Table 2 presents descriptive statistics at the provincial level. The number of observations in most cases is 1293. The first five variables of the table are provincial data collected by ISTAT: per-capita GDP $(Y p c)$; the net number of firms in the Chamber of Commerce registry (Firm_ENR); the labor participation rate (Partrate); the share of cooperative firms as a proxy of social capital (Cooprate); the number of thefts (Robrate). All other variables are obtained by the noted transformation from bank-level data to provincial data using our weighting scheme based on shares of banks' provincial branches. In particular, $B C a$ is the amount of the provincial euro 
Table 2 Provincial-level descriptive statistics, sample 2005-2016

\begin{tabular}{llllllrll}
\hline Variable & Mean & SD & Median & Min & Max & Kurtosis & Skewness & Obs \\
\hline CR & $13,882,479$ & $22,001,935$ & $7,578,433$ & 647,914 & $271,700,000$ & 42.032 & 5.4678 & 1293 \\
Ypc & $22,183.00$ & $5,871.30$ & $22,226.00$ & $11,791.00$ & $47,068.00$ & 3.5184 & 0.49746 & 1293 \\
FIRM_ENR & 3530.4 & 4369.5 & 2371 & 503 & 33,113 & 23.776 & 4.2451 & 1250 \\
PARTRATE & 0.63324 & 0.080759 & 0.669 & 0.406 & 0.761 & 2.224 & -0.706 & 1293 \\
COOPRAT & 0.042584 & 0.015615 & 0.04 & 0.011 & 0.113 & 5.634 & 1.239 & 1285 \\
ROBRATE & 20.444 & 8.7202 & 18.9 & 2.3 & 60.7 & 5.348 & 1.228 & 1254 \\
LR & 0.16334 & 0.055866 & 0.15906 & 0.053915 & 0.40912 & 3.807 & 0.681 & 1293 \\
LEV & 0.21572 & 0.30505 & 0.13696 & 0.013299 & 3.495 & 43.167 & 5.629 & 1293 \\
HI & 0.14312 & 0.092697 & 0.11764 & 0.035529 & 0.7152 & 14.362 & 3.106 & 1293 \\
ROA & 0.00011934 & 0.0065287 & 0.0016783 & -0.028365 & 0.012829 & 3.022 & -0.661 & 1293 \\
SPA & 0.68462 & 0.14663 & 0.68421 & 0.11667 & 1.00000 & 3.690 & -0.132 & 1293 \\
noSPA & 0.31538 & 0.14663 & 0.31579 & 0.00000 & 0.88333 & 3.690 & 0.132 & 1293 \\
BCC & 0.16345 & 0.12423 & 0.15789 & 0.00000 & 0.85000 & 7.676 & 1.411 & 1293 \\
BP & 0.15193 & 0.07870 & 0.15152 & 0.00000 & 0.50000 & 4.717 & 0.526 & 1293 \\
BCa & $37,494.00$ & $118,650.00$ & 3404.50 & 0.00 & $3,033,000.00$ & 330.620 & 14.608 & 1293 \\
BCn & 0.06565 & 0.09591 & 0.02439 & 0.00000 & 0.80769 & 12.235 & 2.488 & 1293 \\
Boa & 9066.00 & $29,912.00$ & 0.00 & 0.00 & $455,000.00$ & 77.680 & 7.182 & 1293 \\
Bon & 0.03177 & 0.05972 & 0 & 0 & 0.40541 & 11.277 & 2.6709 & 1293 \\
\hline & & & & & &
\end{tabular}

Labels: $S D$ standard deviation, $O b s$ observations

Variables: Ypc is per-capita GDP expressed in euros; Firm_ENR is the net number of firms in the Chamber of Commerce registry; Partrate is labor participation rate, Cooprate is the share of cooperative firms; Robrate is number of thefts; $B C a$ is the euro pecuniary fine for credit-related breaches; $B C n$ is the provincial transformation of the bank-in-credit-breach dummy; $B O a$ and $B O n$ are the counterpart of $B C a$ and $B C n$. For all other variables, see the note in Table 1

pecuniary fine for credit-related breaches. Its average is €37,494 and its median its $€ 3404$ implying that few provinces receive relatively high fines, while most are penalized with extremely low euro amounts; cf. the values of the kurtosis, 330.6, and skewness, 14.60. $B C n$ gives a continuous number ranging from 0 to 1 : individual bank-in-credit-breach dummy values are summed over all banks with weights based on branch shares. $B C n=1$ would occur if all banks operating in a given province receive a fine. In our sample, the highest provincial value for $B C n$ is 0.81 ; most values are below the average; cf. the kurtosis, 12.24, and skewness, 2.48.

\section{Empirical Strategy and Results}

Our empirical strategy goes as follow. We estimate Eq. (1) first with fixed time and provincial effects (FE) and then with fixed effects and instrumental variables (FEIV) applying two-stage least squares (2SLS) so as to address endogeneity problems. $^{11}$

\footnotetext{
11 We prefer fixed effects over random effects according to the Hausman's (1978) test.
} 
Three right-hand side variables of Eq. (1) potentially suffer from endogeneity: percapita income, $Y p c$, and the two measures of fines, $B C n$ and $B C a$. Income and credit are positively related. When income starts growing credit tends to move in the same direction, but it is also the case that when credit grows income follows. Hence, we cannot exclude bidirectional causality. A similar argument applies to the relationship between credit and credit-related fines. While the paper starts with the premise that $B C$ has an impact on $C R$, one cannot exclude that, as business conditions and credit deteriorate, supervisors increase their activity and discover more breaches. After all, deficiencies and malfeasance tend to emerge especially in times of distress. We treat the endogeneity issue by utilizing four sets of instruments in the first stage. As in Danisewicz et al. (2017), we include as instrument the non-credit related fines. The reason, as mentioned previously, is that, in addition to following the literature, $B O$ signals the banking legal provincial disposition. We also add indicators of business activity, indicators of social capital, and indicators of criminal activity, all at the provincial level. These variables capture the ease with which one can start and maintain a business in a specific province, a factor that influences the local demand for credit. Apart for the non-credit related fines, the choice for the other instruments was dictated by data availability. Potentially better instruments lacked sufficient coverage or were unavailable at the provincial level. Furthermore, other instruments with a sufficient data coverage turned out to be statistically insignificant and failed to pass basic IV tests; or, if they marginally passed them, the estimated coefficients were not different from those obtained under fixed effects. Our instruments pass endogeneity test (Wooldridge 1995), reject overidentification test (Sargan 1958), and show statistically significant estimated coefficients. For brevity, we report only FEIV estimates using instruments that: (i) have a sufficient data coverage in term of years and provinces (i.e. data availability); (ii) pass basic IV tests suggesting that FEIV estimates are better than straight FE estimates; and (iii) generate statistically significant coefficients that are different from those estimated by FE estimates. In sum, FEIV estimates are more efficient and consistent than FE estimates, but we report both for comparison purposes. We follow the standard procedure to use the residuals of the first stage as regressor in the second stage equation.

Table 3 shows the estimate of Eq. (1) using bank size as the heterogeneity discriminant (i.e., HYP 1-4). Estimates are run under the assumption that banks anticipate the reforms on mutual banks and adjust pre-emptively. The first five columns of the table refer to FEs estimations and the second three refer to FEIV estimations. Column 1 displays the regression of the standard growth model: $\ln C R_{t-1}$ is negative and highly significant; the impact of demand, $\Delta \ln Y p c$, is positive with marginal statistical significance; liquidity $\left(L R_{t-1}\right)$, concentration $\left(H I_{t-1}\right)$, and ownership $(S P A)$ are three among bank supply factors that are statistically significant. Column 2 shows that the provincial fine frequency, $B C n_{t-1}$, has the expected positive impact on the growth of provincial credit (HYP1), while the provincial pecuniary fine, $B C a_{t-l}$, exerts the opposite effect on the growth of provincial credit (HYP2). On the other hand, $\Delta \ln Y p c$ vanishes in statistical significance. Column 3 shows that there are no reputational effects (HYP3). Column 4 tests for asymmetries due to differences in bank size (HYP4). These asymmetric effects cannot be rejected when bank size $\left(\ln C R_{t-1}\right)$ interacts with the frequency of bank fines $\left(B C n_{t-1}\right)$ but are rejected 


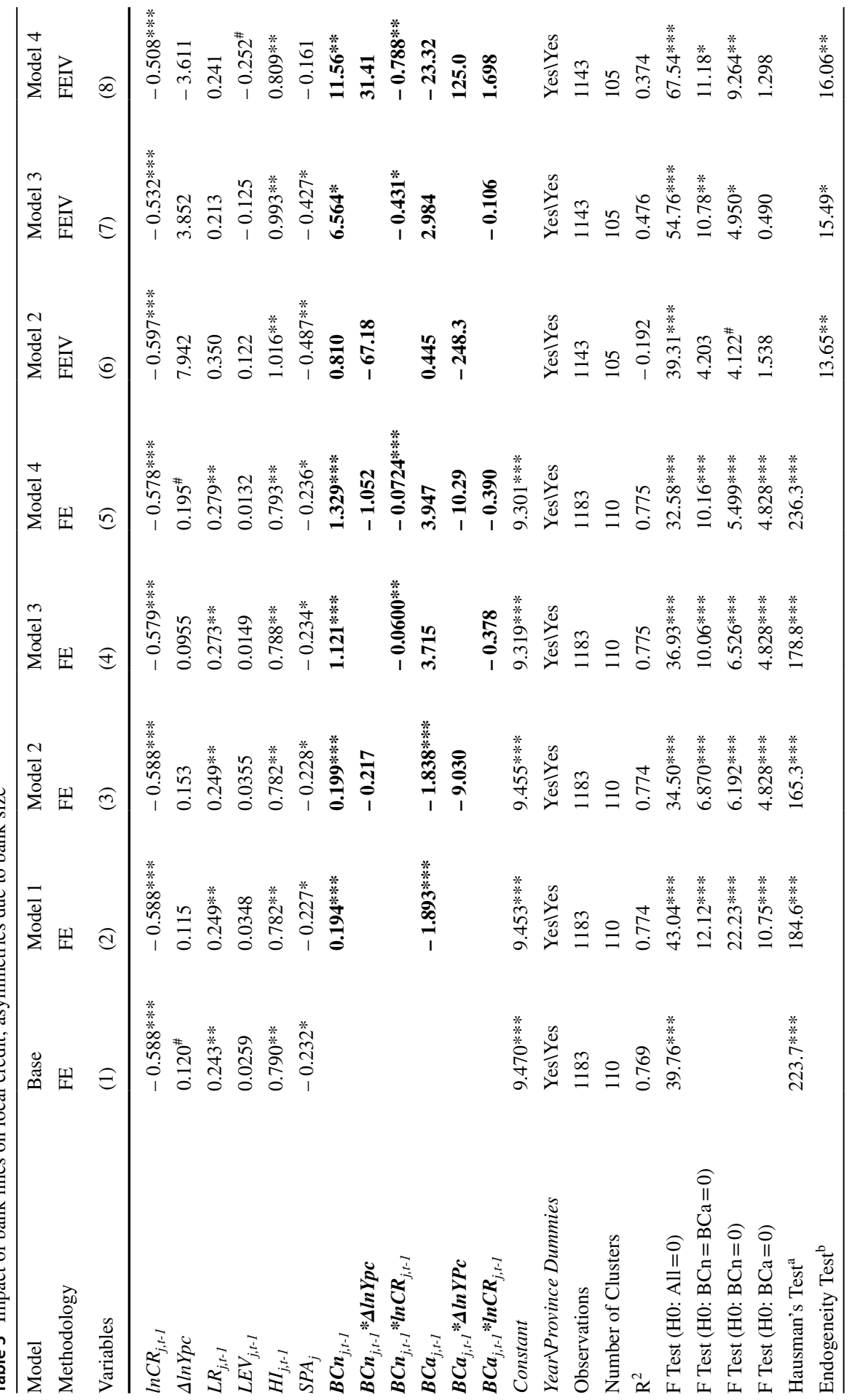




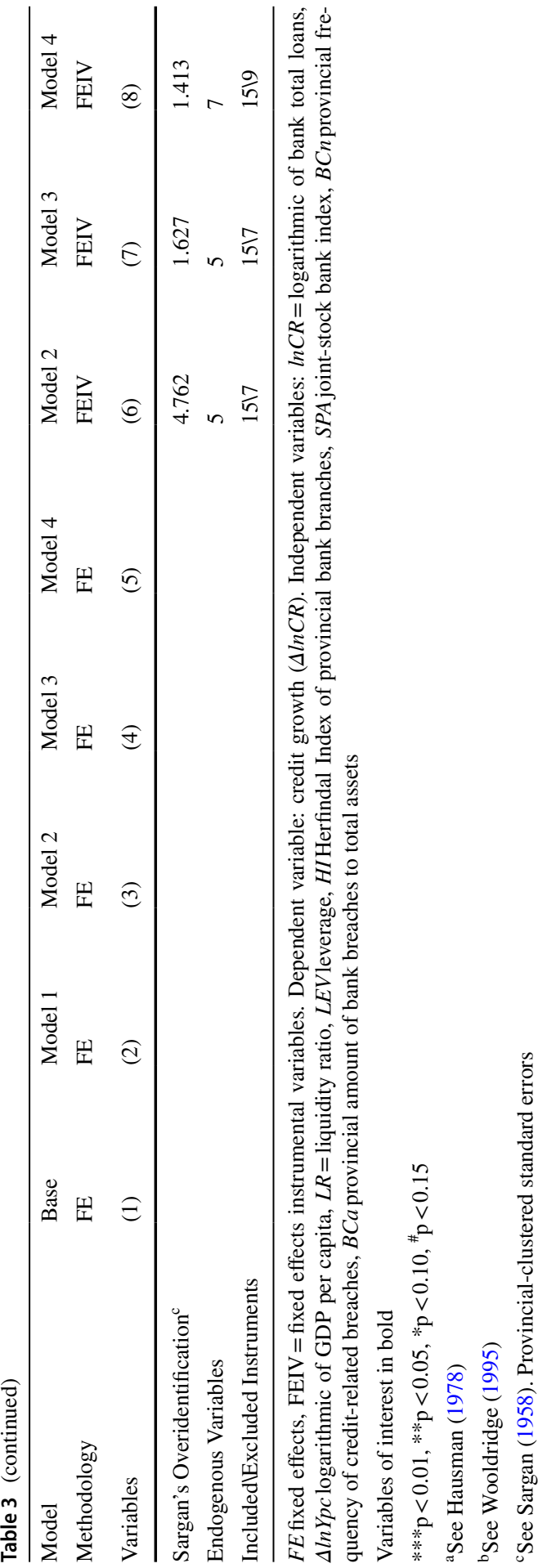


when bank size interacts with the pecuniary fine. These findings are consistent with the proposition that the frequency of breaches is doing the bulk of the work, by triggering a strong "positive" credit adjustment mitigated by a minor "negative" credit adjustment due to the interaction with the bank size; on the other hand, the puny size of the fine does not affect bank behaviour. Column 5 adds reputational terms to the specification of column 4 . These terms are not statistically significant; in contrast, the significance of the bank-size asymmetries is confirmed.

Columns 6 through 8 display the corresponding FEIV regressions of the FE regressions of columns 3 through 5 . The number of endogenous variables ranges from five of column 6 to seven of column 8; the number of exogenous variables ranges is 15 . While there is a clear case of over-identification, the Sargan's test shows that the additional instruments are valid: the endogeneity test passes the hurdle. The key outcome is that the FEIV estimation corroborates the FE estimation. The asymmetric effects due to bank size are restricted to the frequency of breaches; the pecuniary fine appears to be irrelevant: all the $B C a$ coefficients are statistically insignificant (see column 7). When fine variables are combined with reputational terms, the latter vanish, and the former remain significant at the 5\% level (see column 8). Table 3 can be summarized as follows: fine frequency triggers credit reallocation that are sensitive to bank size; pecuniary fines are irrelevant, for which the best explanation is that fines are too small to do the job they are intended to do.

Table 4 considers asymmetries due to bank ownership (HYP5). It implicitly assumes that banks are unable to correctly predict the consequences of reforms on mutual banks or that these reforms are not credible. The structure of the table is similar to Table 3, except that the first two specifications are omitted for brevity. Bank ownership is identified by the two dummy-based variables, SPA and noSPA that interact with $B C n_{j, t-1}$ and $B C a_{j, t-1}$. As $S P A$ and noSPA are complementary by design, of the triplet $B C n_{j, t-1}, B C n_{j, t-1} * S P A$, and $B C n_{j, t-1} * n o S P A$, and the corresponding triplet involving $B C a_{j, t-1}$, only two are independent. In Table 4 , we have dropped the fine variable from the triplet. Therefore, the interaction terms capture the combined direct effect of the fine variable and the indirect effect through the interaction with $S P A$ or noSPA. In column 1 , with FE estimation, $B C n_{j, t-1 * S P A}$ exerts a positive impact on provincial credit growth, whereas $B C a_{j, t-1 * n o S P A}$ pulls in the opposite direction. The interaction terms have high statistical significance. On the other hand, the corresponding interaction terms with noSPA are not statistically significant at the $10 \%$ confidence level. Column 2 adds the reputational term, which is statistically irrelevant. The story changes sharply under FEIV estimations in Columns 3 and 4 , in the sense that none of the four interaction terms are statistically significant. ${ }^{12}$ The economic and statistical significance of bank fines disappears when banks are distinguished according to type of ownership and governance. The popular notion that breaches and fines penalize unduly community banks is not confirmed with this dataset.

\footnotetext{
12 As in Table 3, the estimated equations of Table 4 are over-identified, but with valid instruments according to the Sargan's test. The endogeneity test passes the standard statistical hurdle.
} 
Table 4 Impact of bank fines on local credit; asymmetries due bank ownership

\begin{tabular}{|c|c|c|c|c|}
\hline Model & Model 3 & Model 4 & Model 3 & Model 4 \\
\hline Methodology & $\mathrm{FE}$ & $\mathrm{FE}$ & FEIV & FEIV \\
\hline Variables & (1) & (2) & (3) & (4) \\
\hline $\ln C R_{j, t-1}$ & $-0.587^{* * * *}$ & $-0.587 * * *$ & $-0.567 * * *$ & $-0.593 * * *$ \\
\hline$\Delta \ln Y p c$ & $0.121^{\#}$ & 0.157 & $6.229 *$ & 3.821 \\
\hline$L R_{j, t-1}$ & $0.252 * *$ & $0.252 * *$ & 0.0795 & 0.247 \\
\hline$L E V_{j, t-1}$ & 0.0365 & 0.0371 & -0.0234 & 0.0619 \\
\hline$H I_{j, t-1}$ & $0.780 * *$ & $0.780 * *$ & $0.967 * *$ & $0.878 *$ \\
\hline$S P A_{j}$ & $-0.222^{*}$ & $-0.223 *$ & $-0.561 * *$ & $-0.384 * *$ \\
\hline$B C n_{j, t-l} * \Delta \ln Y p c$ & & -0.226 & & -33.84 \\
\hline$B C n_{j, t-1} * S P A$ & $0.268 * * *$ & $0.273 * * *$ & -0.181 & 0.0916 \\
\hline$B C n_{j, t-1} * n o S P A$ & -0.0559 & -0.0521 & $-\mathbf{2 . 5 2 3}^{\#}$ & -0.931 \\
\hline$B C a_{j, t-1} * \Delta \ln Y p c$ & & -8.014 & & -77.17 \\
\hline$B C a_{j, t-1} * S P A$ & $-4.235 * * *$ & $-4.128 * * *$ & -2.357 & -0.0224 \\
\hline$B C a_{j, t-1} * n o S P A$ & $-1.022^{\#}$ & $-0.980^{\#}$ & $\mathbf{8 . 0 3 3}^{\#}$ & 5.096 \\
\hline Constant & $9.426 * * *$ & $9.428 * * *$ & & \\
\hline YearXProvince Dummies & Yes\Yes & Yes\Yes & YeslYes & Yes\Yes \\
\hline Observations & 1183 & 1183 & 1143 & 1143 \\
\hline Number of Clusters & 110 & 110 & 105 & 105 \\
\hline $\mathrm{R}^{2}$ & 0.775 & 0.775 & -0.009 & 0.532 \\
\hline F Test $(\mathrm{H} 0:$ All $=0)$ & $41.93 * * *$ & $34.82 * * *$ & $39.48 * * *$ & $62.58 * * *$ \\
\hline F Test $(\mathrm{H} 0: \mathrm{BCn}=\mathrm{BCa}=0)$ & $7.174 * * *$ & $5.573 * * *$ & 3.198 & 8.987 \\
\hline F Test $(\mathrm{H} 0: \mathrm{BCn}=0)$ & $12.52 * * *$ & $8.473 * * *$ & 2.728 & $8.068 * *$ \\
\hline F Test $(\mathrm{H} 0: \mathrm{BCa}=0)$ & $5.524 * * *$ & $4.430 * * *$ & 2.554 & 2.947 \\
\hline Hausman's Test ${ }^{\mathrm{a}}$ & $73.89 * * *$ & $416.5^{* * *}$ & & \\
\hline Endogeneity Test ${ }^{\mathrm{b}}$ & & & $12.11 * *$ & $12.38 *$ \\
\hline Sargan's Overidentification ${ }^{c}$ & & & 1.726 & 7.450 \\
\hline Endogenous Variables & & & 5 & 7 \\
\hline Included\Excluded Instruments & & & $15 \backslash 7$ & $15 \backslash 9$ \\
\hline
\end{tabular}

$F E$ fixed effects, FEIV fixed effects instrumental variables. Dependent variable: credit growth $(\Delta \ln C R)$. Independent variables: $\ln C R=\log$ arithmic of bank total loans, $\triangle \ln Y p c$ logarithmic of GDP per capita, $L R=$ liquidity ratio, $L E V$ leverage, $H I$ Herfindal Index of provincial bank branches, SPA joint-stock bank index, noSPA mutual and community bank index, $B C n$ provincial frequency of credit-related breaches, $B C a$ provincial amount of bank breaches to total assets

Variables of interest in bold

$* * * \mathrm{p}<0.01, * * \mathrm{p}<0.05, * \mathrm{p}<0.10$

${ }^{\mathrm{a}}$ See Hausman (1978)

${ }^{\mathrm{b}}$ See Wooldridge (1995)

${ }^{\mathrm{c}}$ See Sargan (1958). Province-clustered standard errors 
In sum, breaches exert an impact on credit reallocation through the signal emanating from its frequency and working through the size of the bank.

\section{Robustness Checks and Counterfactual Exercises}

In this section, we present some robustness checks and two counterfactual exercises that simulate the effects of changes in the frequency of fines and in the size of the provincial banking sector. On robustness of our findings, we perform two econometric exercises. The first consists of adding to specification (1) an additional bank supply variable, the return on assets (ROA). In the second, we add the crisis dummy variable CRISIS, which is equal to one for the years 2008 through 2012. We recall from our discussion of descriptive statistics that a key characteristic of Italian banks was a very low level of efficiency (profitability). ROA has a sample average of $0.22 \%$ and a frequency distribution spanning from a minimum of $-67.9 \%$ to a maximum of $19.8 \%$. As to CRISIS, Italy was particularly penalized by the Great Recession of 2008-2009 and the subsequent sovereign debt turmoil (Bofondi et al 2018). The CRISIS dummy replaces time dummies. In sum, both ROA and CRISIS are good candidates for a robustness exercise.

In Table 5, the 1-year lag of ROA is added in Model 3 and Model 4 of Eq. (1). Model 3 includes the core specification, the two fine variables, and the asymmetries due either to bank ownership or bank size; model 4 adds the reputational term to model 3. The models are estimated, as in the previous two tables, first with FE and then with FEIV. The key result of the table is that ROA does not alter the findings of Tables 3 and 4. ROA then is replaced with CRISIS in Table 6. The difference between the two tables is that CRISIS is very significant, whereas ROA is not. For the rest, the two tables corroborate the findings of Tables 3 and 4.

For the counterfactual scenario, we use the estimate of column 7 in Table 3 to simulate the impact of the statistically significant fine variables on provincial bank credit. We prefer column 7-8 because its specification is more parsimonious. For the simulation, we change the fine frequency, $B C n$, by $\pm 25 \%$ and the provincial banking sector size, $C R_{j, t-1}$, by $\pm 50 \%$. We then calculate the average marginal effects under each scenario. The purpose of the exercise is to compare the two opposing forces acting on provincial bank credit, the push of fine frequency and the pull of bank size. Figure 2 displays nine maps of Italian provinces; the maps code changes in provincial credit according to three colours and their intensity: green for a positive change, white for no change, and red for a negative change. For each row, as we move from west to east provincial bank size changes $(-50 \%, 0,+50 \%)$, for a given provincial fine frequency. For each column, as we move from north to south, provincial fine frequency changes $(-25 \%, 0,+25 \%)$, for a given provincial bank size. The key result is that as we move from the center map (row 2, column 2) to the north eastern map, the color changes from white to predominantly red, and as we move from the center map to the south western map, the color changes to predominantly green. A change in the number of fines exerts an amplification effect on provincial lending activity. This result is in line with Rezende and Wu (2014) who find that, given the minimum frequency of examinations required by US regulation, those 


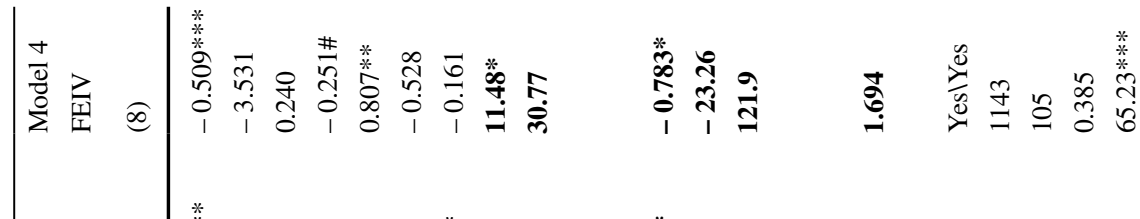

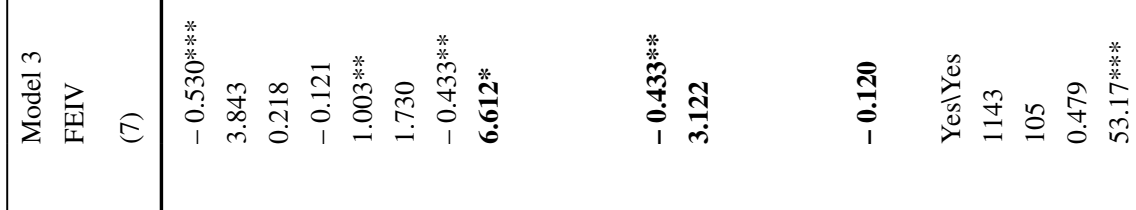

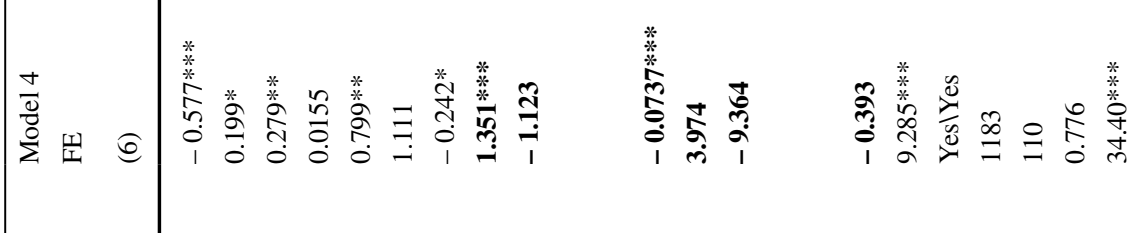

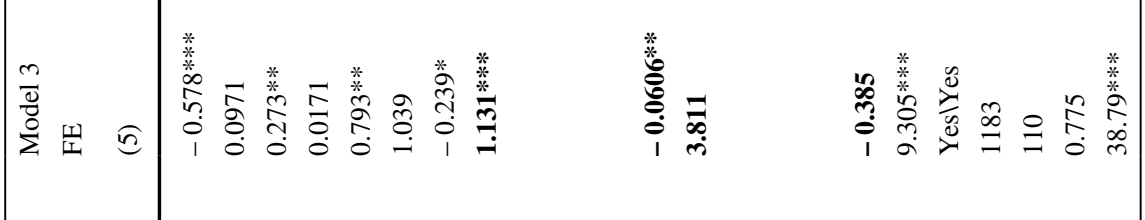

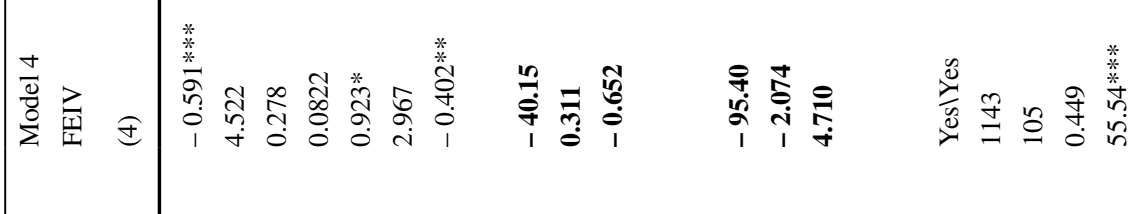

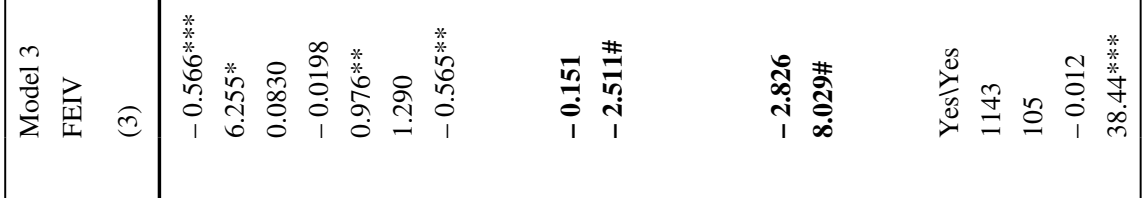

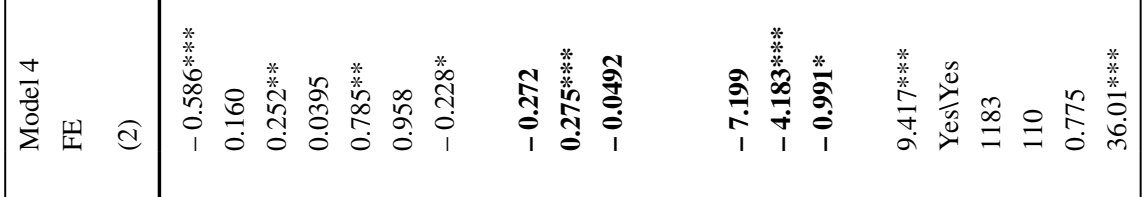

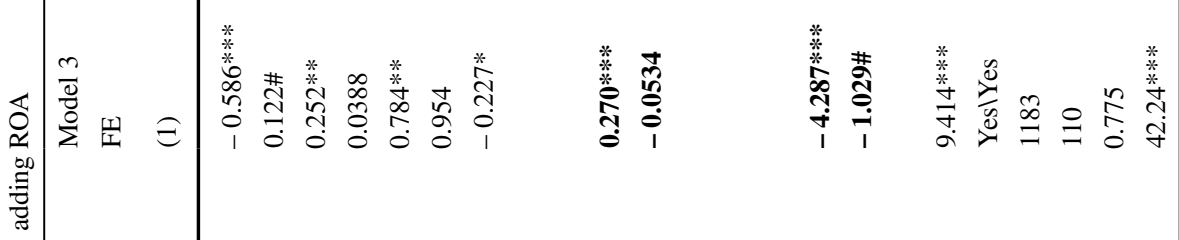

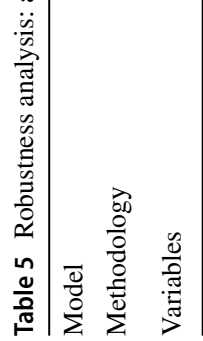

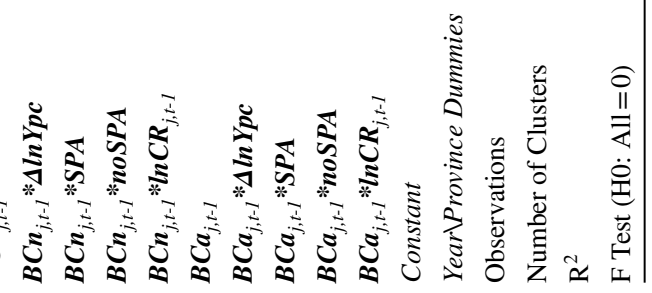




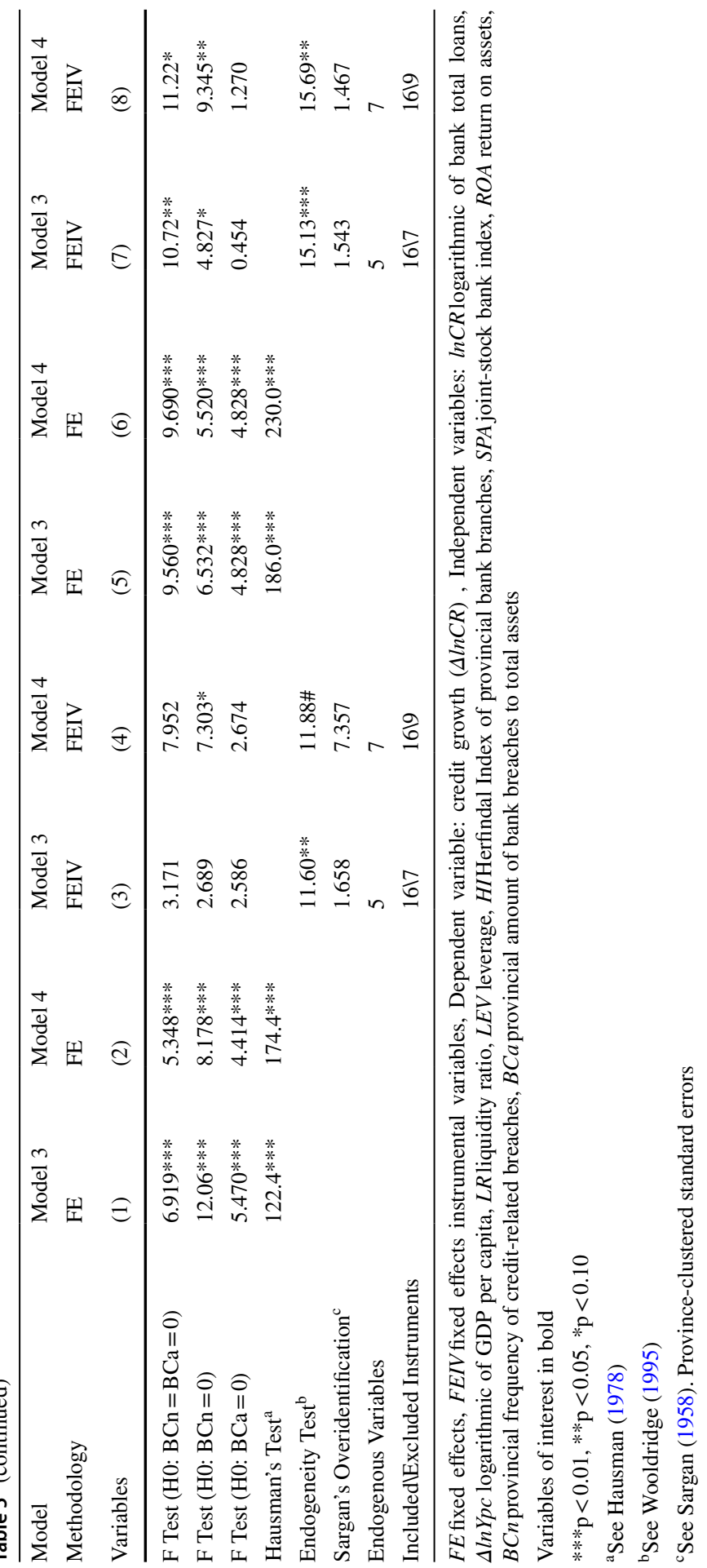




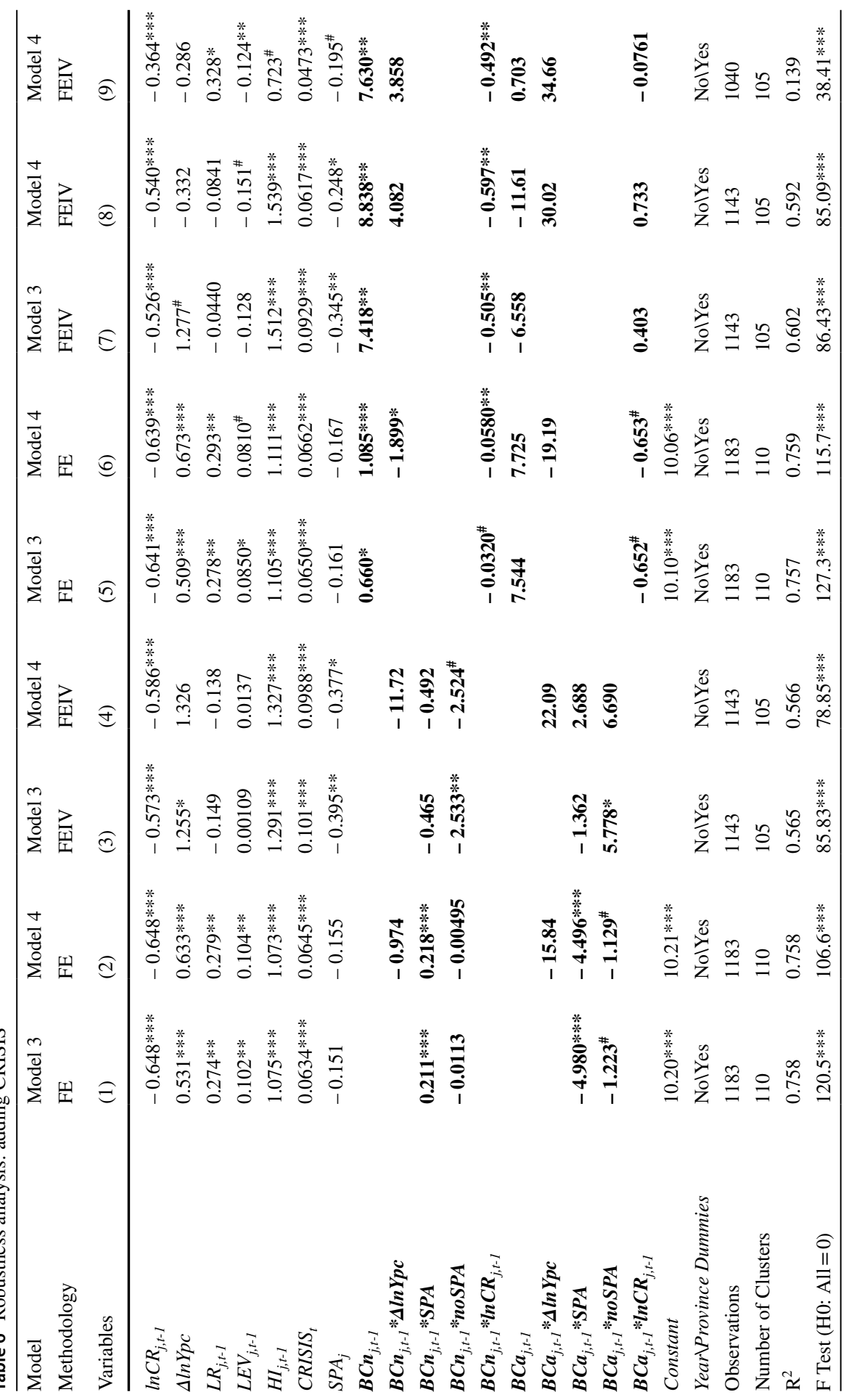




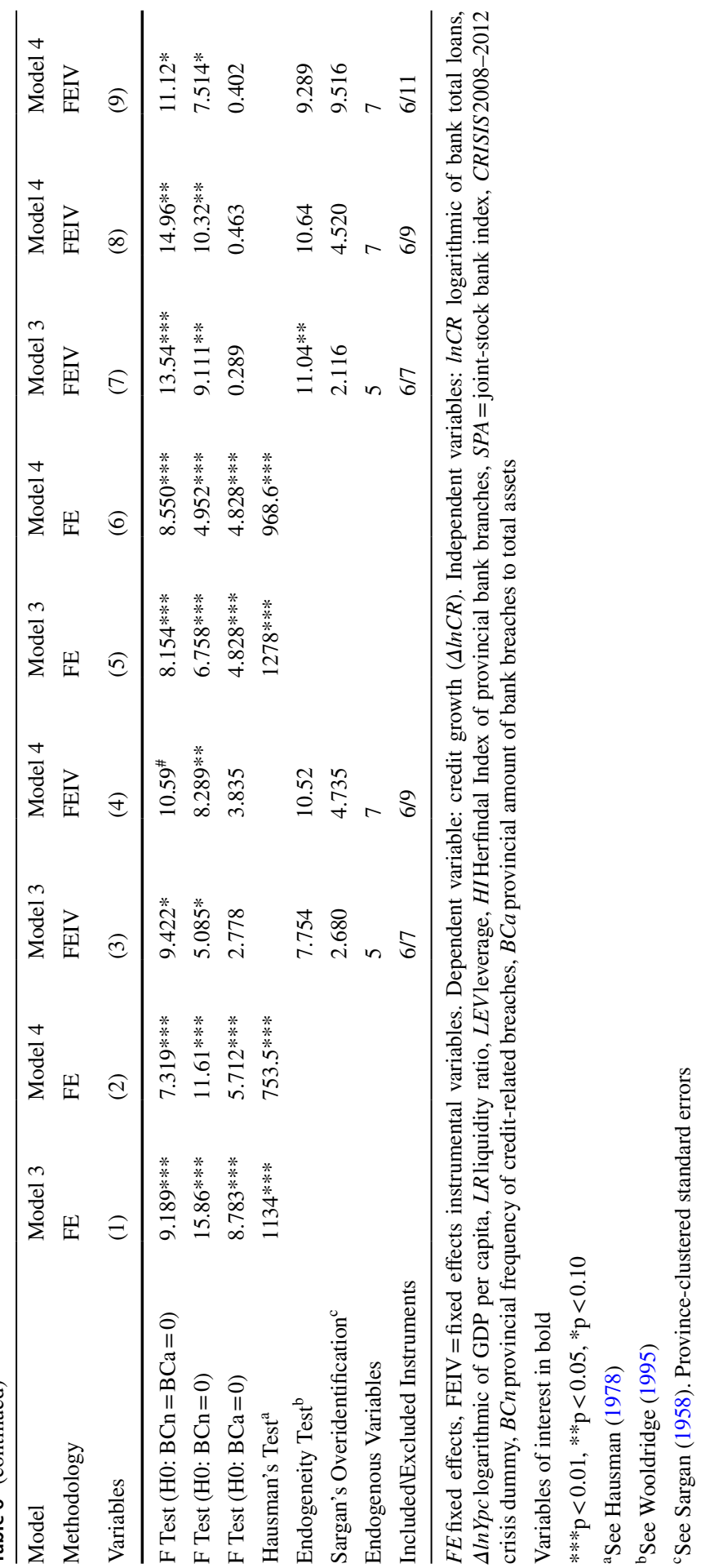




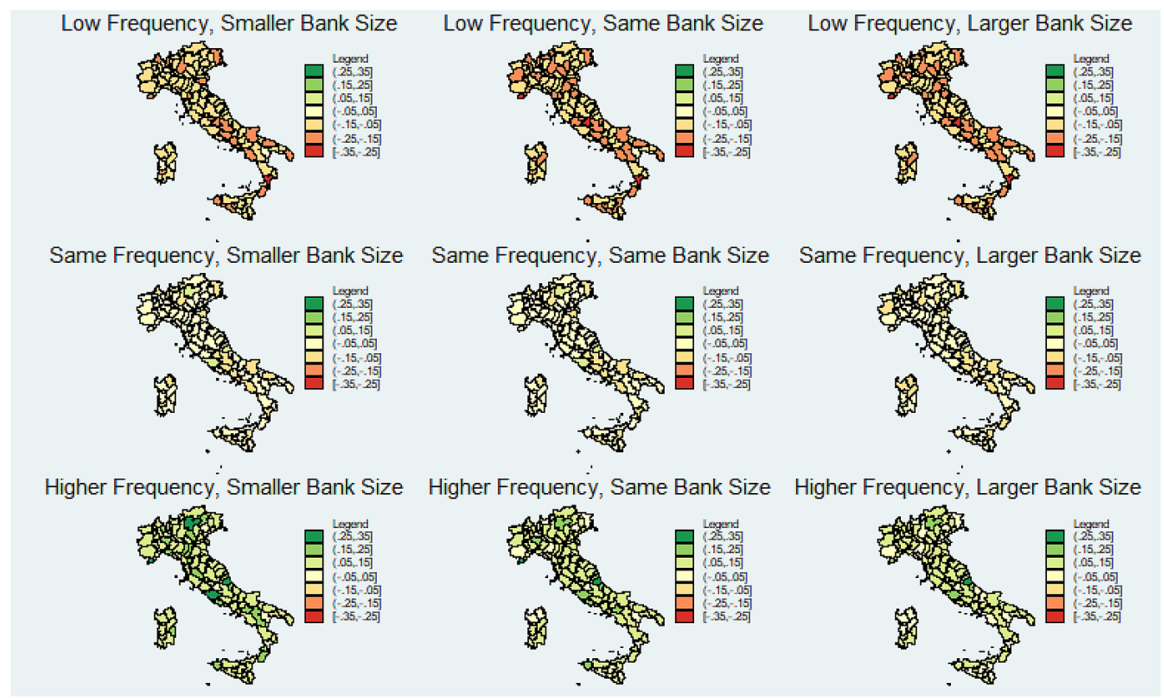

Fig. 2 Simulations of the impact of bank fines, annual average 2005-2016. Low Frequency $=-25 \%$; High Frequency $=+25 \%$. Smaller Bank Size $=-50 \%$; Larger Bank Size $=+50 \%$. Same Frequency, Same Bank Size represents predicted values of column (7) of Table 3

banks that are exempted from examination show lower profitability resulting from increasing loan losses and delinquencies. In essence, an increase in provincial bank credit can be obtained by raising the frequency of bank fines; it supports the notion that fines act more like a good housekeeping seal of approval than a penalty on the banking sector.

Figure 3 shows the provincial distribution of the impact of bank fines. The left panel of the figure, based on the estimate of column 7 in Table 3, shows that given the existing local banking sector size, the impact of fine frequency on provincial credit is negative in about $83 \%$ of Italian provinces. Everything else equal (in particular bank size), a $25 \%$ increase in $B C n$ would shift the distribution sufficiently to the right by making a positive increase in provincial bank credit in all provinces. In sum, fine frequency has a sizeable economic impact on provincial credit.

\section{Conclusions}

Fines are an important enforcement mechanism of bank supervision, and naturally one would expect that they would exert an impact on the credit market. Yet, these actions have received scarce attention in the literature. This paper has examined the nexus between bank fines and provincial bank credit. Theoretically, fines trigger a reputational effect on the demand for credit, and credit reallocation and balance sheet effects on the supply side. Using a dataset of Italian banks over the period 2005-2016, we estimate these effects using a fixed effect model and instrumental variables to remove potential endogeneity problems. The three 

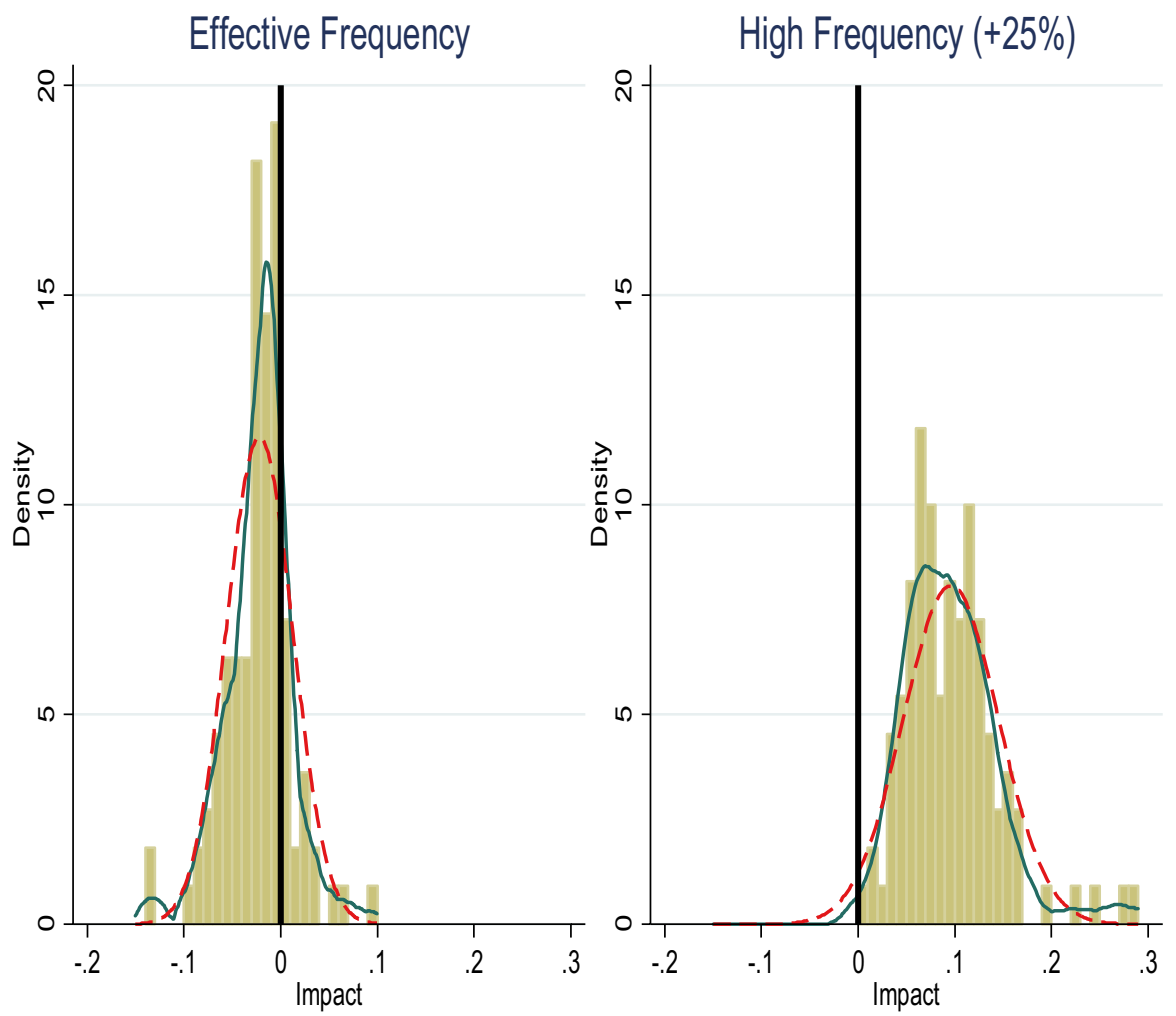

Fig. 3 Impact of bank fines on provincial credit, annual average, 2005-2016

testable implications are: a negative effect on provincial bank credit due to pecuniary fine reducing banks' net income; a positive effect on provincial bank credit due to fines triggering a more efficient and transparent resource allocation; and a reduction of provincial bank credit due to a stigma effect associated with a bank fine. Our key findings are that provincial total bank loans expand following the decision of a fine but are insensitive to the size of the fines.

Compared with the findings in the literature, the novel result of our paper is that bank fines can induce changes in bank management that streamline and increase lending activity at the provincial level. Furthermore, the impact of bank fine frequency on local credit is sensitive to the size of the provincial banking sector but not either to differences in types of bank governance/ownership or to the crisis period of 2008-2012. One explanation for the insensitivity to bank governance/ownership is that banks may have anticipated the policy reforms of 2016. Finally, we find no evidence of either reputational or other balance sheet effects. Our policy recommendation is that it would behoove bank supervisors to raise the frequency over the size of bank fines. The latter seem to work more like a good housekeeping seal of approval, enhancing transparency and effective banking practices, and less like a penalty. 


\section{Appendix: Construction of Provincial Breach Variables}

In the following table we illustrate the transformation of bank-level breach variables in provincial breach variables: the notation is: $\mathrm{x}=$ breach amount, $\mathrm{d}=$ breach dummy, $\mathrm{y}=$ total assets and $\mathrm{z}=$ breach amount $/$ total assets. Observed data are shown in bold.

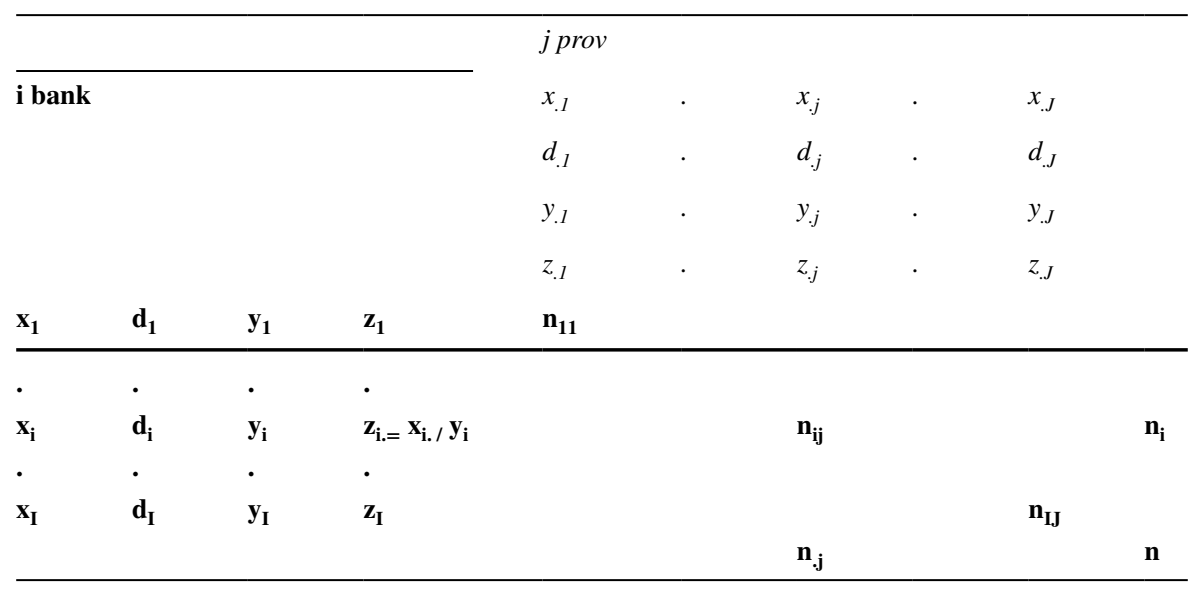

As we do not know the provincial allocation of an individual bank's breach, we assume that it is proportional to the relative incidence of branches. This allows to construct a continuous variable from a dummy $=1$ when there is a breach and zero otherwise. In the dataset, this variable is denoted by $B C$, i.e. the (relative) number of credit-related breaches. For pecuniary sanctions, we construct a weighted provincial breach and weighted provincial bank assets, each of which aggregated as shown above, and then calculate the ratio. The two weighted sums reflect the relative incidence of banks in the province (numerator) and the relative bank size in the province (denominator). In the dataset, this variable is shown as $B C a$, i.e. the amount of the sanction (See Tables 7, 8 and 9). 


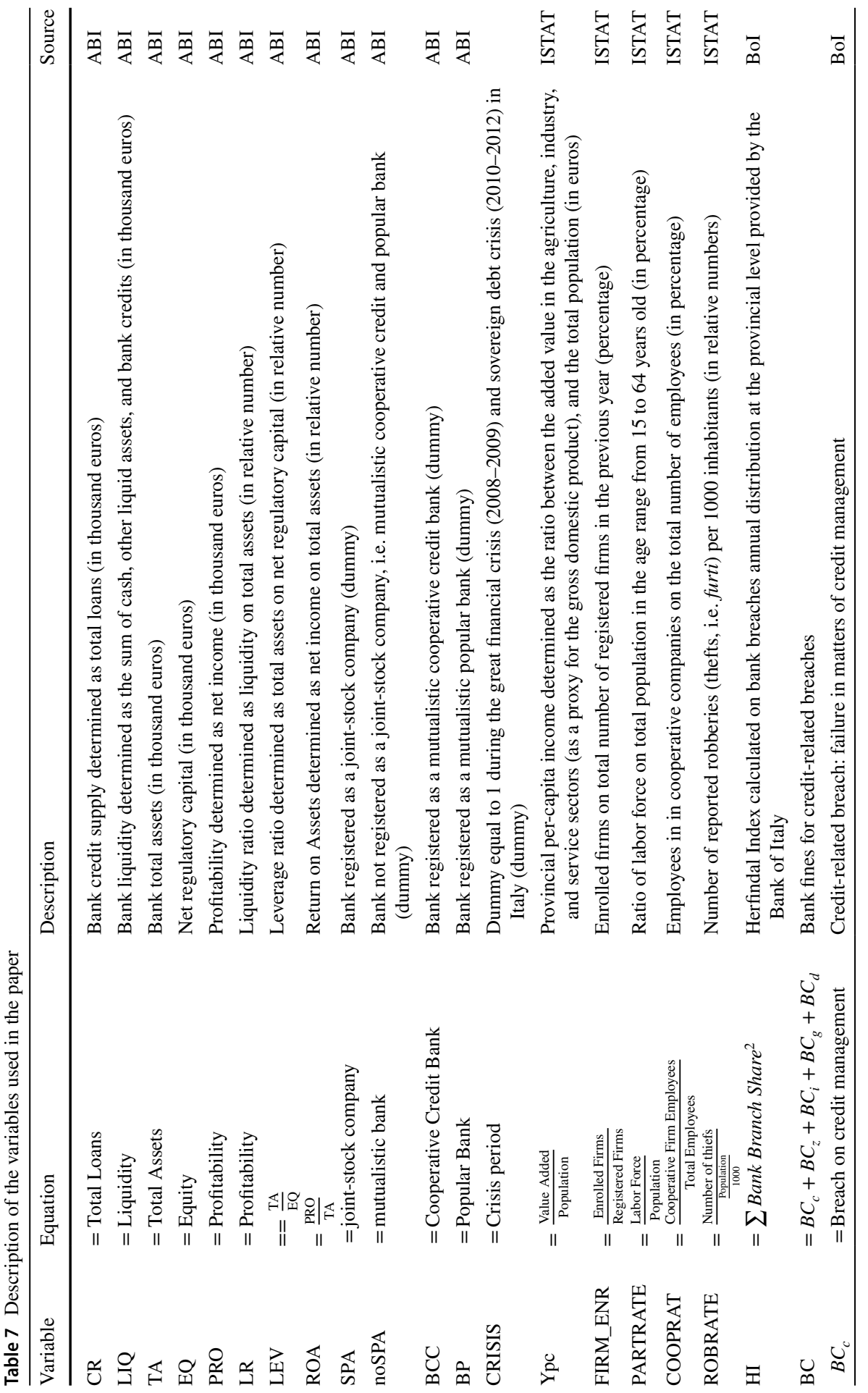




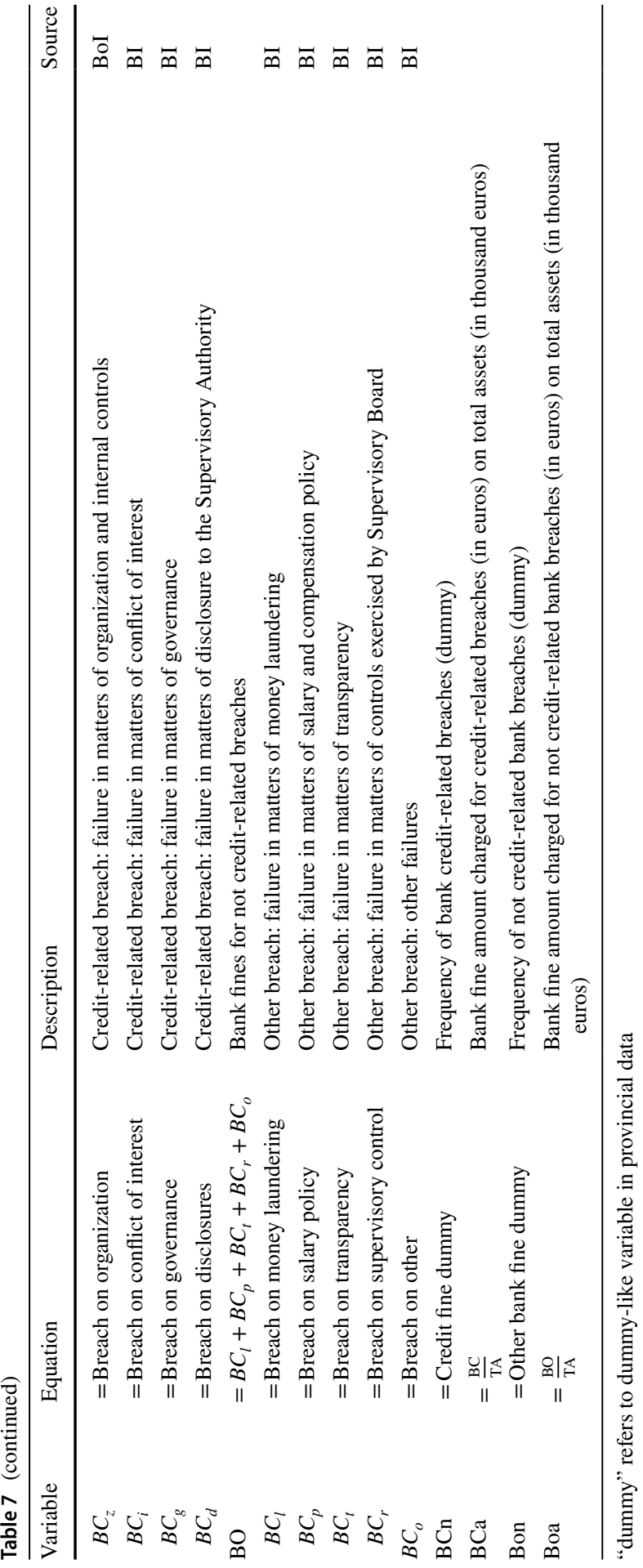




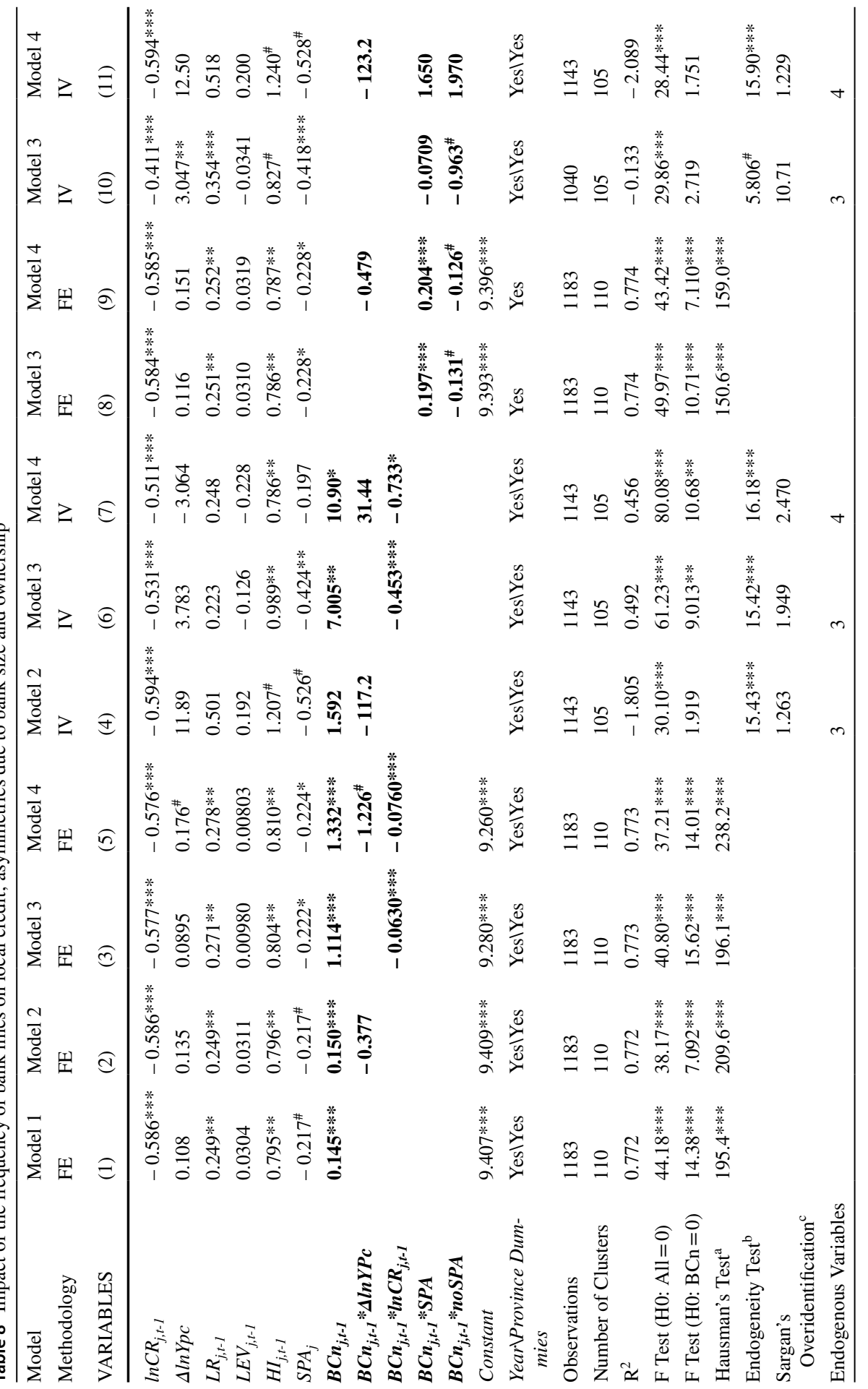




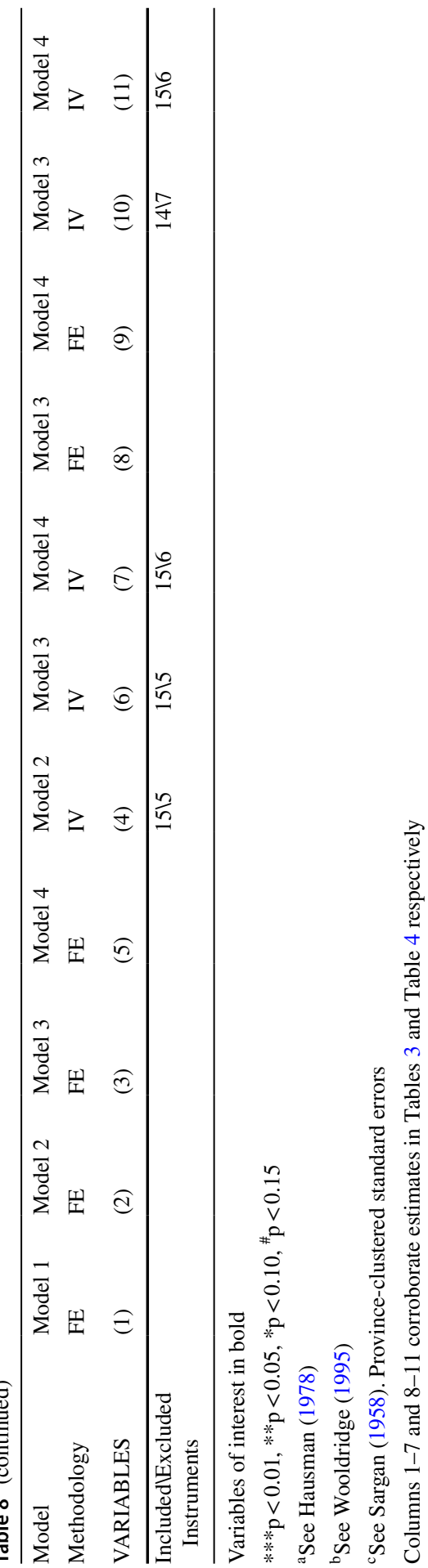




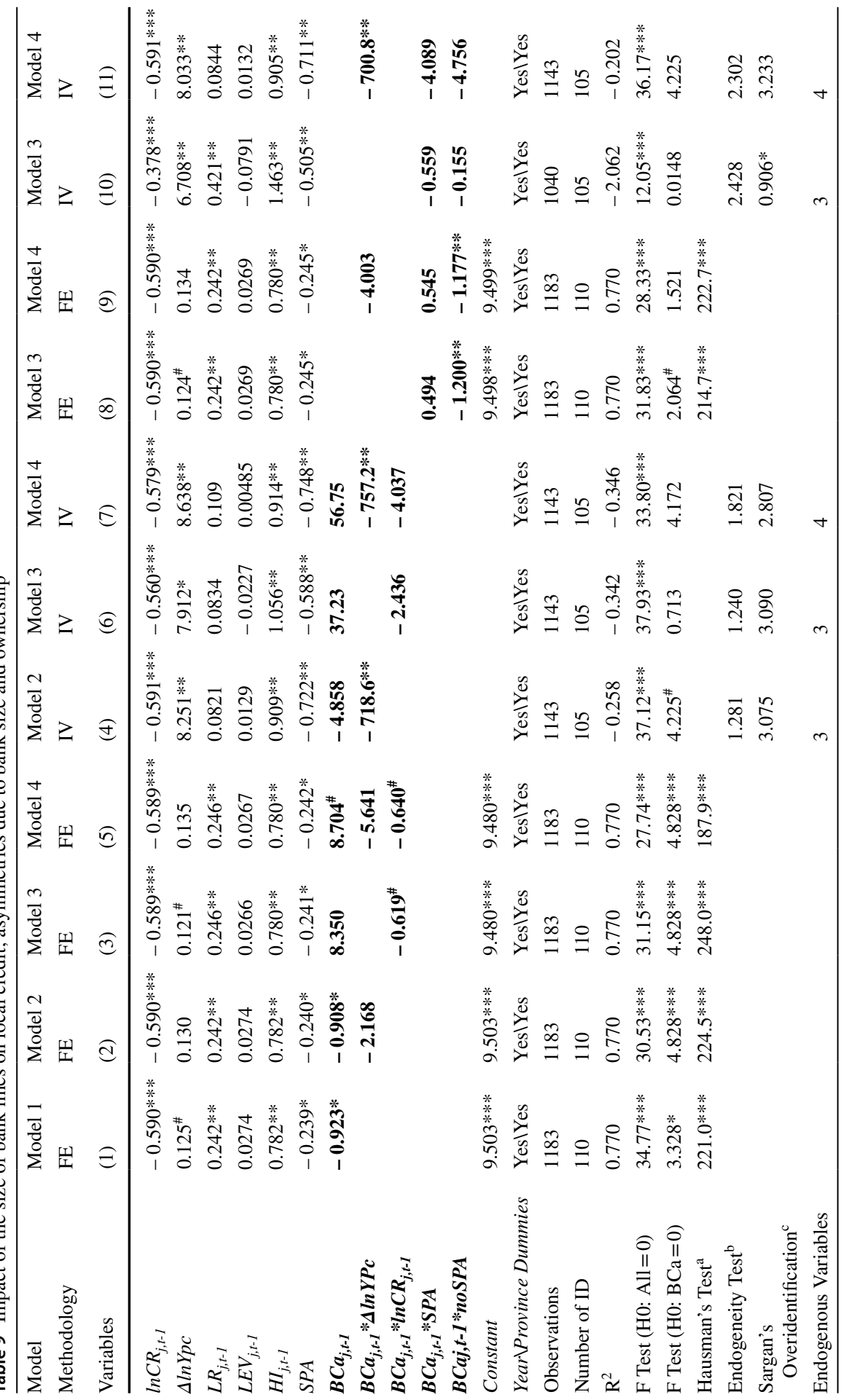




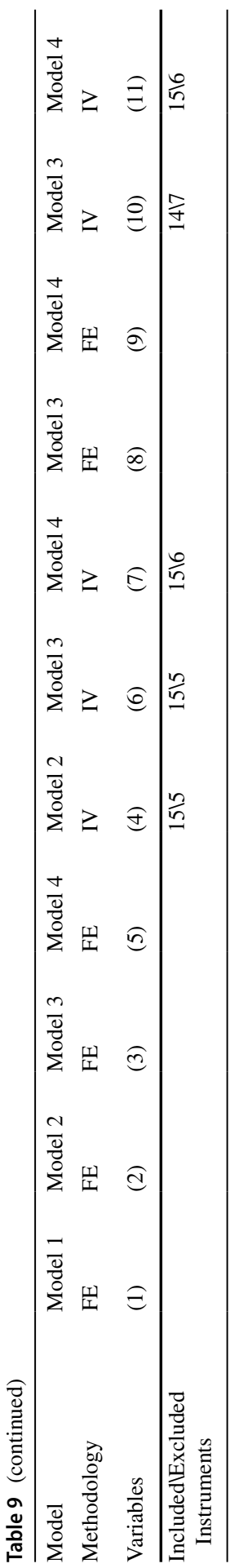


Funding Open access funding provided by Università Politecnica delle Marche within the CRUI-CARE Agreement.

Open Access This article is licensed under a Creative Commons Attribution 4.0 International License, which permits use, sharing, adaptation, distribution and reproduction in any medium or format, as long as you give appropriate credit to the original author(s) and the source, provide a link to the Creative Commons licence, and indicate if changes were made. The images or other third party material in this article are included in the article's Creative Commons licence, unless indicated otherwise in a credit line to the material. If material is not included in the article's Creative Commons licence and your intended use is not permitted by statutory regulation or exceeds the permitted use, you will need to obtain permission directly from the copyright holder. To view a copy of this licence, visit http://creativecommons.org/licen ses/by/4.0/.

\section{References}

Agarwal S, Lucca D, Seru A, Trebbi F (2014) Inconsistent regulators: evidence from banking. Q J Econ 129:889-938

Alessandrini P, Presbitero A, Zazzaro A (2010) Bank size or distance: what hampers innovation adoption by SMEs. J Econ Geogr 10:841-885

Barro RJ (1991) Economic growth in a cross section of countries. Q J Econ 106(2):407-443

Bassett WF, Lee SJ, Spiller TP (2015) Estimating changes in supervisory standards and their economic effects. J Bank Finance 60:21-43

Berger A, Bouwman C, Kick T, Schaeck K (2016) Bank liquidity creation following regulatory interventions and capital support. J Financ Intermed 26:115-141

Bofondi M, Carpinelli L, Sette E (2018) Credit supply during a sovereign debt crisis. J Eur Econ Assoc 6(3):696-729

Bonfim D, Cerqueiro G, Degryse H, Ongena S (2020) On-site inspecting zombie lending. Centre for Economic Policy Research, London

Caiazza S, Cotugno M, Fiordelisi F, Stefanelli V (2018) The spillover effect of enforcement actions on bank risk-taking. J Bank Finance 91:146-159

Coccorese P, Shaffer S (2018) Cooperative banks and local economic growth, Working Paper at Società Italiana degli Economisti, October

Danisewicz P, McGowan D, Onali E, Schaeck K (2017) The real effects of banking supervision: Evidence from enforcement actions. J Financ Intermed 35:1-16

Deli Y, Delis M, Hasan I, Liu L (2019) Enforcement of banking regulation and the cost of borrowing. J Bank Finance 101:147-160

Delis MD, Staikouras PK (2011) Supervisory effectiveness and bank risk. Rev Finance 15:511-543

Delis MD, Staikouras PK, Tsoumas C (2017) Formal enforcement actions and bank behavior. Manag Sci 63:959-987

Eber M, Minoiu C (2016). How Do Banks Adjust to Stricter Supervision? Available at https://ssrn.com/abstr act=2662502 or https://doi.org/10.2139/ssrn.2662502

Fonteyne W (2007). Cooperative banks in Europe-policy issues. IMF Working Paper, 07/159

Giordano F (2007) Storia del Sistema bancario italiano. Donzelli Editore

Hausman JA (1978) Specification tests in econometrics. Econometrica 46:1251-1271

Hirtle B, Kovner A, Plosser M (2019). The impact of supervision on bank performance. Federal Reserve Bank of New York, Staff Reports n.768

Kim D, Mckillop D (2019) Community banking institutions. In: Berger A, Molyneux P, Wilson J (eds) The Oxford handbook of banking, 3rd edn. Oxford University Press, Oxford

King RG, Levine R (1993) Finance and growth: Schumpeter might be right. Q J Econ 108:717-737

Law SH, Singh N (2014) Does too much finance harm economic growth? J Bank Finance 41:36-44

Leuz C, Granja J (2019) The death of a regulator: strict supervision, bank lending, and business activity. CFS Working Paper Series n. p 610

Levine R, Loayza N, Beck T (2000) Financial intermediation and growth: causality and causes. J Monet Econ 46:31-77 
Lucchetti R, Papi L, Zazzaro A (2001) Banks inefficiency and economic growth: a micro-macro approach. Scot J Polit Econ 48:400-424

Mankiw N, Romer D, Weil D (1992) A contribution to the empirics of economic growth. Q J Econ 107:407-437

Passalacqua A, Angelini P, Lotti F, Soggia G (2020) The real effects of bank supervision: evidence from onsite bank inspections. Harvard University Working Paper

Peek J, Rosengren E (1995) Bank regulation and the credit crunch. J Bank Finance 19:679-692

Rezende M, Wu JJ (2014) The effects of supervision on bank performance: evidence from discontinuous examination frequencies. In: Midwest Finance Association 2013 Annual Meeting

Sargan JD (1958) The estimation of economic relationships using instrumental variables. Econometrica 26:393-415

Stefani ML, Vacca V, Coin D, Del Prete S, Demma C, Galardo M, Garrì I, Mocetti S, Pellegrino D (2016). Le banche locali e il finanziamento dei territori: Evidenze per l'Italia (2007-2014). In: Banca d'Italia, Questioni di Economia e Finanza, n.324

Usai S, Vannini M (2005) Banking structure and regional economic growth: lessons from Italy. Ann Reg Sci 39:691-714

Visco I (2018) Anni difficile. Dalla crisi finanziaria alle nuove sfide per l'economia. il Mulino, Bologna

Wooldridge JM (1995) Score diagnostics for linear models estimated by two stage least squares. In: Rao CR, Maddala GS, Phillips PCB, Srinivasan TN (eds) Advances in econometrics and quantitative economics: essays in honor of professor. Blackwell, Oxford, pp 66-87

Publisher's Note Springer Nature remains neutral with regard to jurisdictional claims in published maps and institutional affiliations. 